\title{
AGRAVOS À SAÚdE DE AUXILIARES DE ENFERMAGEM RESULTANTES DA EXPOSIÇÃO OCUPACIONAL AOS RISCOS FÍSICOS
}

Marina Pereira Rezende

Dissertação de Mestrado
apresentada à Escola de
Enfermagem de Ribeirão Preto da
Universidade de São Paulo, para
concorrer ao Título de Mestre, pelo
curso de Pós-Graduação em
Enfermagem - Área de
concentração:
Fundamental.

Ribeirão Preto 2003 


\section{UNIVERSIDADE DE SÃO PAULO \\ ESCOLA DE ENFERMAGEM DE RIBEIRÃO PRETO}

\section{AGRAVOS À SAÚDE DE AUXILIARES DE \\ ENFERMAGEM RESULTANTES DA EXPOSIÇÃO \\ OCUPACIONAL AOS RISCOS FÍSICOS}

Marina Pereira Rezende

Dissertação de Mestrado
apresentada à Escola de
Enfermagem de Ribeirão Preto da
Universidade de São Paulo, para
concorrer ao Título de Mestre, pelo
curso de Pós-Graduação em
Enfermagem - Área de
concentração:

Orientadora: Prof ${ }^{a}$ Dr ${ }^{a}$ Maria Lúcia do Carmo Cruz Robazzi

Ribeirão Preto 


\section{FICHA CATALOGRÁFICA}

Rezende, Marina, P.

Agravos à saúde de Auxiliares de Enfermagem resultantes da exposição ocupacional aos Riscos Físicos. Ribeirão Preto, 2003.

114 p. : il. ; $30 \mathrm{~cm}$

Dissertação de Mestrado, apresentada à Escola de Enfermagem de Ribeirão

Preto/USP - Departamento de Enfermagem Geral e Especializada.

1. Saúde do trabalhador

2. Auxiliares de enfermagem

3. Enfermagem

4. Riscos Ocupacionais

5. Riscos Ocupacionais Físicos 


\section{SUMÁRIO}

RESUMO

ABSTRACT

RESUMEN

1. INTRODUÇÃO

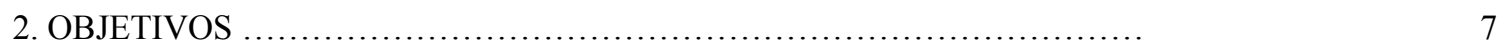

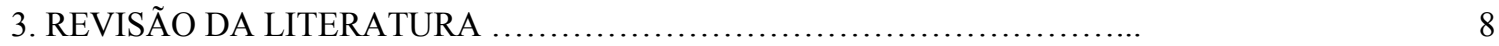

3.1 - Trabalho e processo em saúde-doença em instituições hospitalares $\quad 8$

3.2 - A Enfermagem, seu trabalho e suas categorias profissionais ........ 13

3.3 - Riscos ocupacionais relacionados ao trabalho de enfermagem ........ 18

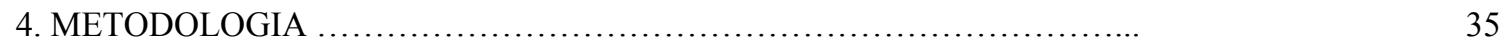

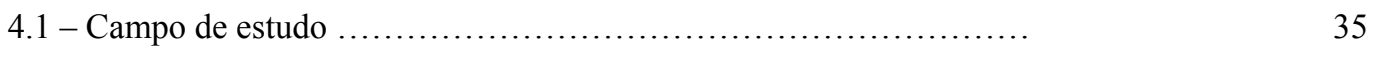

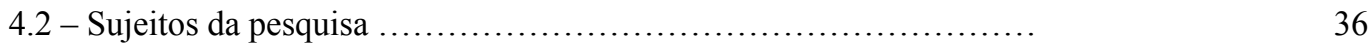

4.3 - Procedimentos metodológicos .............................. 37

$4.4-$ Aspectos éticos da pesquisa $\ldots \ldots \ldots \ldots \ldots \ldots \ldots \ldots \ldots \ldots \ldots \ldots \ldots \ldots \ldots$

5. APRESENTAÇÃO E DISCUSSÃO DOS DADOS ........................... 39

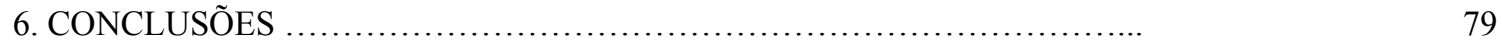

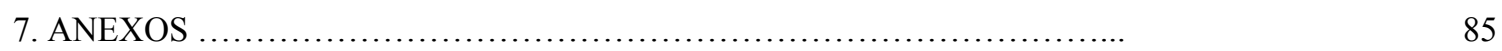

8. REFERÊNCIAS BIBLIOGRÁFICAS ................................. 91 


\section{LISTA DE FIGURAS}

p.

Figura 1 - Distribuição de auxiliares de enfermagem de um Hospital Escola, segundo as suas respostas quanto à identificação sobe risco físico Uberaba, MG, $2003(n=85)$.

Figura 2 - Agentes de risco físico e algumas alterações de saúde a ele relacionadas

Figura 3 - Agentes de risco e alterações de saúde codificados conforme CID

10 (1993) verbalizados pelos auxiliares de enfermagem. 


\section{LISTA DE TABELAS}

TABELA1- Distribuição de auxiliares de enfermagem de um Hospital Escola segundo o sexo, estado civil, idade e o grau de escolaridade. Uberaba, MG, 2003 (n = $85)$

TABELA 2- Distribuição de auxiliares de enfermagem de um Hospital Escola, segundo as horas trabalhadas por semana, a existência de outro emprego e o setor de trabalho, Uberaba, MG, 2003, $(\mathrm{n}=85)$

TABELA 3: Distribuição de auxiliares de enfermagem de um Hospital Escola, segundo as suas respostas quanto à identificação dos agentes propiciadores de risco físico, Uberaba, MG, 2003 $(n=85)$

TABELA 4: Distribuição de alterações de saúde relatadas por 60 auxiliares de enfermagem de um Hospital Escola. Uberaba, MG, 2003 (n=102).

TABELA 5: Distribuição de auxiliares de enfermagem de um Hospital Escola, segundo, as sua respostas sobre os risos ocupacionais e fatores propiciadores de riscos, Uberaba, MG, 2003 $(n=47)$

TABELA 6: Distribuição de auxiliares de enfermagem de um Hospital Escola segundo as suas respostas quanto ao uso de Equipamentos de Proteção Individual. Uberaba, MG, 2003 $(n=85)$

TABELA 7: Distribuição de auxiliares de enfermagem de um Hospital Escola segundo as suas respostas quanto as medidas de prevenção relacionadas aos agentes de riscos físicos Uberaba, MG, $2003(n=85)$ 


\section{Data da Defesa: 29/12/2003}

\section{Banca Examinadora:}

Profa. Dra. Maria Lúcia do Carmo Cruz Robazzi

Julgamento: Assinatura

Prof ${ }^{a}$. Dr ${ }^{a}$. Maria Helena Palucci Marziale

Julgamento:

Assinatura

Prof ${ }^{a}$. Dr ${ }^{a}$. Maria Inês Monteiro Cocco

Julgamento:

Assinatura 


\section{RESUMO}

\section{REZENDE, M.P. Agravos à saúde de auxiliares de enfermagem} resultantes da exposição ocupacional aos riscos físicos. 2003.114p.Dissertação Mestrado - Escola de Enfermagem de Ribeirão Preto, Universidade de São Paulo, Ribeirão Preto.

O presente estudo teve como objetivo geral identificar os agravos à saúde de auxiliares de enfermagem provenientes da exposição a riscos físicos; sendo os específicos, investigar se os auxiliares de enfermagem identificam os agentes propiciadores de risco físico no ambiente de trabalho hospitalar; identificar os problemas de saúde que os acometem os auxiliares de enfermagem e identificar, dentre os problemas de saúde que os acometem, aqueles que podem ser resultantes da exposição aos riscos físicos. Trata-se de um estudo seccional, não-experimental, de caráter descritivo, com análise quantitativa de dados, coletados através de entrevista estruturada com a utilização de um questionário. Constituíram-se sujeitos do estudo 85 auxiliares de enfermagem. As alterações de saúde mencionadas por esses trabalhadores foram codificadas de acordo com Classificação Internacional de Doenças e Problemas Relacionados à Saúde. Os resultados revelaram que a maioria dos entrevistados pertence ao sexo feminino (82,3\%); $41,2 \%$ eram casados e $35,3 \%$ solteiros; $40 \%$ trabalhavam 36 horas semanais e $29,4 \%$ dos trabalhadores possuíam outro emprego. Em relação às informações acerca da identificação do risco ocupacional físico apenas 30,6\% possuía informações corretas. 51,8\% dos auxiliares de enfermagem mencionaram já ter sofrido acidentes de trabalho e $81,58 \%$ os identificaram aos riscos biológicos. Em relação às alterações de saúde, os auxiliares de enfermagem apresentaram dorsalgia não especificada e dor lombar baixa (21,57\%); cefaléia (13,73\%); rinite alérgica inespecífica, sinusite crônica não especificada, amigdalite aguda não especificada, afecções respiratórias devido a agentes não especificados; hipertensão secundária não especificada $(8,82)$; mialgia e dor em membro (5,9\%); dentre outras. Entre essas queixas evidenciou-se que algumas podem ter acontecido em decorrência dos agentes de risco físico, tais como; hipertensão, estresse, transtorno de ansiedade relacionado ao ruído; hemorragia não classificada a outra parte, que podem ser provenientes das radiações ionizantes; história pessoal de alergias a drogas, medicamentos e substâncias não especificadas, excesso de exercícios e movimentos rigorosos ou repetitivos, advindas do excessivo calor; cefaléia, proveniente da iluminação inadequada, dentre outras. Apesar dos agentes de risco físico estarem presentes no ambiente de trabalho hospitalar, onde atuam os auxiliares de enfermagem, esses não conseguem, em sua maioria identificá-los; Evidenciou-se que os sujeitos do presente estudo relatarem fazer uso de alguns Equipamentos de Proteção Individual, com certa freqüência; entretanto confundiram algumas medidas de prevenção aos riscos físicos com tais equipamentos. No contexto estudado, evidenciou-se que os auxiliares de enfermagem, apresentam dificuldade na identificação dos riscos ocupacionais físicos, mesmo trabalhando em ambientes onde tais riscos estão presentes. Estratégias foram propostas no sentido de minimizar os problemas levantados.

Palavras-chave: Riscos ocupacionais, riscos ocupacionais físicos, auxiliares de enfermagem, acidente de trabalho, alterações de saúde, enfermagem. 


\section{RESUMEN}

REZENDE, M.P. Los daños de salud de auxiliares de enfermeria derivados de la exposión ocupacional a riesgos físicos. 2003. 110p. Tesis (Maestria). Escuela de Enfermeria de Ribeirão Preto, Universidad de São Paulo, Ribeirão Preto.

El presente estudio tuvo como objetivo identificar los daños a la salud de auxiliares de enfermería derivados de la exposición del trabajador a riesgos físicos. Tuvo como objetivos especific investigar si los auxiliares de enfermería pueden identificar los factores de riesgo físico en el ajuste del trabajo del hospital; identifique los problemas de salud que los afectan y, identificar los problemas que pueden ser debido a la exposición los riesgos físicos. El Estudio fue compuesto por 85 auxiliares de enfermería. La categorización estuvo determinada por la literatura sobre riesgos y enfermedades ocupacionales, accidentes de trabajo, y alteraciones de salud relatadas por los auxiliares. La mayoría de los entrevistados pertenece al sexo femenino, $(82.3 \%)$; 41,2\% son casados e 35,3\% solteros. La Mayoría (40\%) refirió trabajar 36 horas por semana y $29,4 \%$ refirieron trabajar en otro empleo. Apenas el $(30,6 \%)$ de los entrevistados consiguen identificar el concepto de riesgo ocupacional físico. En cuanto al accidente de trabajo el 51,8\% de los auxiliares mencionaron haberlo sufrido y el $81,58 \%$ identifican estos accidentes de trabajo con los riesgos biológicos. En relación a las alteraciones de salud, con base en el relato de los trabajadores y en la literatura consultada, los auxiliares de enfermería presentan hipertensión, y alteraciones gástricas, que pueden ser relacionadas con el ruido; alteraciones y hemorragia gástricas derivadas de las radiaciones ionizantes, fatiga, y reacciones dermatológicas, resultado del excesivo calor, entre otros. A pesar de que los agentes de riesgo físico se encuentran presentes en el ambiente de trabajo en el hospital donde actúan, los auxiliares de enfermería en su mayoría no consiguen identificarlos; por otro lado presentan numerosas alteraciones de salud, afectando varios segmentos del cuerpo, así como accidentes de trabajo y entre estos problemas de salud, varios pueden estar relacionados a los agentes-factores de riesgos físico presentes en el hospital. Se evidencio que los sujetos participantes del presente estudio hacen uso de los equipos de protección personal, discriminados en el instrumento de colecta de datos, con una cierta frecuencia, además de que algunos confundieron las medidas de prevención con los equipos de protección personal. En el contexto estudiado, se puede observar que los auxiliares de enfermería, presentan dificultad para definir e identificar los riesgos ocupacionales físicos, y se presentan enfermos en cuanto a la cantidad de alteraciones de salud referidas por ellos. Fueron propuestas estrategias en el sentido de mejorar los conocimientos de estos auxiliares de enfermería.

Palabras Clave: Riesgos ocupacionales, Auxiliares de Enfermería, Accidentes y enfermedades ocupacionales. 


\section{ABSTRACT}

REZENDE, M.P. Nurse assistants' health aggravation as a result of occupational exposure to physical risks. 2003. 110p. Dissertação Mestrado Escola de Enfermagem de Ribeirão Preto, Universidade de São Paulo, Ribeirão Preto.

The present study has as objective to identify the nurse assistants' health aggravation as a result of occupational exposure to physical risks that were identified by the nursing professional. It relates to a descriptive research with quantitative analysis of data, collected through structured interview by using a questionnaire. Seventy nurse assistants were the subjects of this study. The health alterations mentioned by those workers were codified according to the International Classification of Diseases and Problems Related to Health (1993). The results revealed that most of the interviewees are female $(81.4 \%) ; 37.1 \%$ were married and the same percentile applies to the bachelors; $42.86 \%$ worked 36 weekly hours and $30 \%$ of the workers had another job. In relation to the information concerning the identification of the physical occupational risk, only $31.4 \%$ had correct information. Regarding the occurrence of Work Accident, 54.3\% of nurse assistants said they had already had those accidents and $81.58 \%$ identified them to the biological risks. In relation to health alterations, the nurse assistants presented non specific backache and low lumbar pain (19.80\%); migraine (12.09\%); non specific secondary hypertension (7.7\%); myalgia and painful member (5.49\%); non specific allergic rhinitis (4.39\%) and equal percentile to non specific nuisance of intervertebral disk, stress and personal history of allergies to medicines and non specific substances, among others. Among those alterations, it was evidenced that some might have happened due to the physical risk agents, such as hypertension, stress, anxiety related to the noise; non classified bleeding that may come from ionizing radiations; personal history of allergies to medicines and non specific substances, exhaustion due to an intense effort and excessive heat; migraine originated from inadequate illumination, among others. Even though some physical risk agents were present in the working hospital atmosphere where the nurse assistants work, those assistants, most of the times, cannot identify them; It was evidenced that the subjects of the present study report to be using some Individual Protection Equipments with a certain frequency; though they confused some prevention procedures to physical risks with such equipments. In the studied context, it was evidenced that the nurse assistant had difficulty identifying the physical occupational risks; even working in an atmosphere where such risks are present. Strategies were proposed in the sense of minimizing the aroused problems.

Key-words: Occupational risks, physical occupational risks, nurse assistant, work accident, health alterations, nursing. 
Dedico este trabalho a meus pais, Sebastião e Maria Edith, que com este jeito todo especial de ser me ensinaram a lutar, a respeitar o ser humano e me incentivam a caminhar. Obrigada. 
Dedicatória

Aos meus irmãos, Márcia, Marília e Marco Antonio, pelo apoio e dedicação nos meus momentos difíceis.

Aos meus sobrinhos, Rafael, Ana Carolina, Marcos Alexandre e Mário Vitor, pela doçura, meiguice e carinho apresentado por cada um de formas diferentes, me proporcionando felicidade.

Ao Adirlei, pelo amor, apoio, paciência, companheirismo, que em momento algum mediu esforços para me ajudar.

Obrigada, pelo carinho e dedicação de todos vocês. 


\section{Agradecimentos}

Agradeço a Deus e a todas as pessoas que contribuíram para a realização deste estudo, em especial:

À Prof ${ }^{a}$ Dra. Maria Lúcia do Carmo Cruz Robazzi, pela dedicação e competência, incentivo e respeito aos meus limites, sendo não só orientadora, mas também amiga.

À Ana Rita, ao Ricardo, a Cristina, a Clair e a Zilda, por serem amigos de todas as horas.

A Prof ${ }^{a}$ Maria Helena Palucci Marziale e Profa Maria Inês Monteiro Cocco pela contribuição, e disponibilidade em dividir conhecimentos.

À Direção de Enfermagem, Serviço de educação continuada e aos Auxiliares de Enfermagem do referido Hospital, que tornaram possível a realização deste estudo.

Aos colegas da Unidade Básica de Saúde "Juca Inácio", pela colaboração, incentivo e amizade.

Aos colegas da Universidade de Uberaba, pela força e colaboração.

À Escola de Enfermagem de Ribeirão Preto - USP, a diretoria, corpo docente e funcionários, pelo apoio e acolhimento.

À Cristiane Aparecida Silveira, pela força, colaboração e companheirismo. 


\section{INTRODUÇÃO}

Desde o ingresso no curso de graduação em enfermagem, em 1991, esta autora vem se interessando pelas questões relacionadas à saúde do trabalhador.

$\mathrm{Na}$ ocasião, observou que os trabalhadores de Enfermagem tinham pouco cuidado relacionado à utilização de Equipamentos de Proteção Individual (EPI) e quase não utilizavam medidas de prevenção quanto aos agentes/fatores de riscos ocupacionais, como, por exemplo, a realização de punção venosa sem luvas, o não uso de máscara para aspiração de pacientes traqueostomizados, o posicionamento do corpo de forma inadequada para transferir pacientes da maca para a cama ou da cadeira para maca ou leito, entre outros. Essa inadequação parecia acontecer, em maior intensidade, entre os trabalhadores de enfermagem de nível médio, particularmente os auxiliares de enfermagem visto que as suas atividades eram, de modo geral, mais intensas e penosas do que aquelas dos demais componentes da equipe de enfermagem.

Após o término do Curso de Graduação em Enfermagem, em busca de maior qualificação sobre tal temática, realizou o curso de especialização em Enfermagem do Trabalho. Particularmente a sua atenção começou a se direcionar para vários problemas que acometem os trabalhadores da área de saúde. Observou, empiricamente, que essas pessoas esforçam-se muito e obrigam o seu próprio organismo a suportar excesso de atividades árduas que desenvolvem, dificultando, dessa forma, a manutenção da sua higidez. Essa realidade parece acontecer com vários trabalhadores da área da saúde, envolvidos com os aspectos da saúde e da doença do ser humano. 
Um dos problemas que contribui para aumentar a vulnerabilidade dos trabalhadores do setor saúde no Brasil é a sua incipiente formação em assuntos relativos à saúde do trabalhador. Isso reforça a presença de dois importantes fatores influentes na ampliação dos riscos ocupacionais: a ignorância do risco e a dificuldade para compreender, aceitar e atender as medidas de higiene e segurança (Bulhões, 1994).

Acresce-se a isso que grande parte dos profissionais da saúde encontrase trabalhando em ambientes hospitalares.

Sabe-se que esses locais constituem os estabelecimentos:

“... normalmente associados à prestação de serviços à saúde, visando a assistência, o tratamento e a cura daqueles acometidos pela doença. No entanto, podem ser também responsáveis pela ocorrência de uma série de riscos à saúde daqueles que ali trabalham...” (Barbosa, 1995, p. $32)$.

“... Como ambiente entende-se o espaço fisicamente determinado e especializado para o desenvolvimento de determinada(s) atividade(s), caracterizado por dimensões $e$ instalações diferenciadas...” (Brasil, 1994, p.43).

“... O hospital é um estabelecimento de saúde dotado de internação, meios diagnósticos e terapêuticos, com o objetivo de prestar assistência médica curativa e de reabilitação, podendo dispor de atividades de prevenção, assistência 
ambulatorial, atendimento de urgência/emergência e de ensino/pesquisa...” (ANVISA, 2002, p. 123).

“... Seja público ou privado, o hospital representa a emergência de interesses submersos da produção industrial na Saúde. O que aparece, todavia, é o seu resultado mais brilhante e socialmente aceito: o cuidado com o enfermo" (Ribeiro, 1993, p. 30).

Uma vez que o hospital apresenta-se como principal meio ambiente laboral para os trabalhadores de enfermagem, faz-se necessário considerar que tal ambiente é nocivo e pode trazer conseqüências graves, dada a exposição diária dessas pessoas a esse local reconhecidamente insalubre (Bulhões, 1994).

Os trabalhadores da área da saúde geralmente ingressam no mercado de trabalho desconhecendo a rotina e cuidados apropriados para evitar a exposição aos riscos presentes no ambiente hospitalar e, conseqüentemente, aos problemas de saúde advindos da exposição ocupacional a esses riscos. Além disso, após a admissão em tais instituições, muitos permanecem sem treinamento e orientações sobre os fatores de riscos presentes na área hospitalar e sobre quais as precauções que devem considerar.

De modo geral, apreende-se que são poucos os trabalhadores preparados para o trabalho em hospitais, inclusive pelo fato de não terem uma cultura prevencionista nos locais de trabalho (Proteção, 1996).

No Brasil, parece que uma grande parte dos hospitais brasileiros procura ocultar os riscos. Na realidade não se sabe se realmente tais riscos são ocultados voluntariamente ou se os administradores não conhecem todos os riscos a que a 
população trabalhadora esta exposta, visto que o número de informações que lhes são passadas acaba sendo muito restrito.

Os esforços dos profissionais do Serviço Especializado de Engenharia de Segurança e Medicina do Trabalho (SEESMT), desses locais, acabam se tornando isolados e a direção dos hospitais parece ou não quer entender a situação. Em muitas situações, os membros do SEESMT necessitam brigar pelos direitos dos trabalhadores, às vezes indo contra e outras a favor das administrações. O trabalho desenvolvido por esses serviços, nos hospitais, depende de vontade, disposição e conscientização da direção hospitalar. Os problemas de se ter uma política de prevenção não diferem muito de uma empresa para um hospital (Proteção, 1996).

Diante do exposto, apreende-se que os trabalhadores dos hospitais estão submetidos às diversas situações de risco e, conseqüentemente, podem adoecer ou acidentar-se em decorrência das condições em que esse trabalho ocorre e da sua maior ou menor aproximação aos agentes propiciadores de tais riscos.

Acredita-se que para preservar a saúde, é necessário que o trabalhador esteja inserido, não só no universo do seu trabalho, mas também no mundo exterior (do lazer, da família) que o beneficia interiormente, visto que este conjunto complementa-se para que ele permaneça em equilíbrio e obtenha a satisfação no seu cotidiano. O trabalho pode lhe oferecer condições para que ele satisfaça as suas necessidades básicas e também as psicossociais, necessárias à manutenção da saúde.

Entre os vários tipos de trabalhadores da área da saúde e que, em sua grande maioria, trabalham em hospitais, encontram-se aqueles de enfermagem. Sabe-se que essa é uma profissão predominantemente feminina, relacionada ao o ato de cuidar do outro. 
Até o final da Idade Média, o trabalho de enfermagem foi executado por religiosas, viúvas, virgens e nobres, tendo como objetivo central a caridade. Atualmente, a assistência é exercida por ambos os sexos, mas ainda prepondera o sexo feminino.

É conhecida a ideologia que, até hoje, tende a predominar, às vezes, nessa profissão: o importante é cuidar do outro, com o máximo de competência e dedicação, procurar salvar-lhe a vida, minimizar-lhe as dores, ouvir suas queixas, confortá-lo, não sendo dada muita importância ao aumento de carga horária laboral, ao cansaço que o trabalhador acaba apresentando, às condições inapropriadas para se trabalhar, à falta de horário para alimentação, sono, repouso, lazer, entre outros problemas.

A enfermagem é subdividida, historicamente, em categorias. Atualmente, no Brasil, há três, quais sejam: o enfermeiro, o técnico de enfermagem e o auxiliar de enfermagem. Há ainda que se considerar a existência de parteiras.

Ao enfermeiro cabe exercer todas as atividades de enfermagem, incluindo direção, chefia de serviço e de unidade de enfermagem: planejamento, organização, coordenação, execução e avaliação dos serviços de assistência de enfermagem, realização de cuidados de maior complexidade técnica e que exijam conhecimentos de base científica e capacidade para tomar decisões imediatas, realização de consulta de enfermagem, entre outras atividades (COREN-MG, 2001).

O técnico de enfermagem exerce atividades de nível médio, envolvendo orientação e acompanhamento do trabalho de enfermagem em grau auxiliar e participação no planejamento da assistência de enfermagem (COREN-MG, 2001). 
O auxiliar de enfermagem exerce atividades de nível médio, realizando serviços sob supervisão, bem como realiza a participação, em nível de execução simples, em processos de tratamento (COREN-MG, 2001). Na maioria dos hospitais, é ele que acaba ficando responsável pelo ato de cuidar em si, ou seja, realiza os cuidados denominados "diretos" * aos pacientes, quais sejam: banhos, limpeza das excretas e secreções, coleta de urina e outros líquidos corpóreos para exames mais simples, troca de roupas pessoais e das camas, limpeza dos móveis adjuntos ao leito e do próprio, entre outras atividades que pressupõem o contato físico muito próximo ao indivíduo enfermo.

As dificuldades de compreensão sobre os riscos ocupacionais e da não aceitação em cumprir as medidas de higiene e segurança ainda permanecem como fatores marcantes nos trabalhadores de enfermagem, possivelmente devido à falta de formação e conhecimentos teóricos sobre tais riscos, bem como sobre a questão ideológica explicitada anteriormente, que os impedem de perceber e, conseqüentemente, de prevenir-se contra os agentes propiciadores dos mesmos.

Partindo da hipótese de que os profissionais de enfermagem, e entre esses os auxiliares de enfermagem, em geral, não possuem conhecimentos teóricos e orientação quanto aos riscos ocupacionais a que estão expostos e as medidas a serem tomadas após acidentes e exposição aos riscos, pretende-se, com este estudo, investigar se essa categoria de trabalhadores (auxiliares de enfermagem), percebe a sua exposição aos agentes/fatores de riscos ocupacionais, especialmente aos riscos físicos que muitas vezes acabam sendo imperceptíveis porque os trabalhadores se acostumam com os mesmos e os seus efeitos nocivos à saúde.

\footnotetext{
* As aspas são da autora, MPR, 2003.
} 


\section{OBJETIVOS}

Constituíram objetivos do presente estudo:

\section{Geral}

Identificar os agravos à saúde de auxiliares de enfermagem provenientes da exposição aos riscos físicos.

\section{Específicos}

- Investigar se os auxiliares de enfermagem identificam os agentes propiciadores de risco físico no ambiente de trabalho hospitalar;

- Identificar os problemas de saúde que acometem os auxiliares de enfermagem e

- Identificar, dentre os problemas de saúde que acometem os auxiliares de enfermagem, aqueles que podem ser resultantes da exposição aos riscos físicos. 


\section{REVISÃO DE LITERATURA}

\subsection{Trabalho e processo saúde-doença em instituições hospitalares}

Entende-se por trabalho “... uma atividade coordenada, de caráter físico e/ou intelectual, necessária à realização de qualquer tarefa, serviço ou empreendimento...” (Ferreira, 2001). “... É a aplicação das atividades físicas e intelectuais; serviço; esforço..." (Rocha \& Pires 2000).

O trabalho constitui-se em atividade social e também o caminho para conseguir integração e sociabilidade, a maneira pela qual se obtém o respeito e o reconhecimento dos companheiros, o modo de se ter amigos e estabelecer vínculos sociais (Perez, apud Nicolete, 2001).

“... Um dos fatores importantes na vida das pessoas é o trabalho. Na maioria das vezes é sentido como um fardo pesado: no entanto, também pode ser apreendido como algo que dá sentido à vida e eleva o “status”...” (Nicolete, 2001).

“... É definido como o processo de intercâmbio material entre o homem e a natureza no qual o homem atua, intencionalmente, sobre os elementos da natureza transformando-os em valores de uso em atendimento às suas necessidades” (Marx, p. 149 -163, apud Antunes 1999). 
“... É uma relação social, fundamental para a existência humana e mais, que envolve dimensões estéticas, culturais, artísticas e de lazer..." (Frigotto, 1987).

“... É o modo como o homem produz e reproduz sua existência. Ao fazê-lo, estabelece relações sociais e objetiva sua subjetividade...” (Almeida \& Rocha, p.23, 1997).

“... É entendido como o resultado da combinação do objeto, dos meios, da força e do produto do trabalho. $O$ objeto é a matéria com que se trabalha; os meios de trabalho são os instrumentos que o homem utiliza; a força de trabalho é a energia humana empregada no processo de transformação; o produto é o valor criado pelo trabalho, é o valor de uso...” (Braverman, 1980).

Japiassu \& Marcondes (p.236, 1993), apud Cocco (2002), relatam que, na Antiguidade, enquanto os gregos consideravam o trabalho como expressão da miséria do homem, os latinos opunham o otium (lazer, atividade intelectual) ao vil negotium (trabalho, negócio).

Arendt (p. 12, 1993), apud Cocco (2002) explica que a era moderna trouxe consigo a glorificação teórica do trabalho, e resultou na transformação efetiva de toda a sociedade em uma sociedade operária, sendo o trabalho fundamental para a sua manutenção. 
Ressalta-se que essa modificação no modo de se entender o trabalho, surgiu diante da necessidade de se ter mão-de-obra trabalhando, de maneira fragmentada e alienada, sem realizar grandes questionamentos, o que aconteceu em decorrência da Revolução Industrial e implementação do jeito de pensar capitalista. Assim, de algo vil e direcionado aos escravos, a partir dessa nova ideologia, o trabalho passou a ser encarado como atividade importante, na qual ficou revestida a questão de religiosidade e nobreza.

“... A otimização do trabalho é um fator fundamental para o sucesso de pessoas e organizações, num mundo de alta competição, onde saúde e excelência de desempenho são aspectos fundamentais...” (Rio, 1999).

Analisando os conceitos anteriormente citados, pode-se perceber que os autores, em sua maioria, entendem que o trabalho existe para satisfazer o homem, pois, através da execução de suas atividades, ele consegue reproduzir e estabelecerse na sociedade.

Quanto à saúde, sabe-se que há a clássica definição da Organização Mundial de Saúde que preconiza ser essa situação não apenas a ausência de doença, mas a condição de perfeito bem-estar físico, mental e social. Nesse sentido (Ferraz \&Segre, 1997), apontam as situações de, no momento, tal entendimento ser irreal, ultrapassado e unilateral.

A saúde é entendida como qualidade do que é sadio ou são; bom estado do organismo, cujas funções estão regulares (Rocha \& Pires, 2000). 


\begin{abstract}
“... Ter saúde é condição sine qua non, para o desempenho e a produtividade ótimos. Fatores tais como motivação, treinamento e comprometimento compõem com a saúde o conjunto de condições que permitem às pessoas tornarem o trabalho um diferencial competitivo da mais alta importância estratégica para as organizações...” (Rio, 1999).
\end{abstract}

A saúde resulta da relação de um homem historicamente localizado com uma função específica no sistema de produção e sua respectiva inserção no meio natural e social, sob a influência direta de fatores socioeconômicos e culturais como educação, habitação, alimentação, renda, meio ambiente, trabalho, transporte, lazer, liberdade, acesso à moradia e aos serviços de saúde, conforme disposto na $8^{\mathrm{a}}$ Conferência Nacional de Saúde (BRASIL, 1986).

Sugerem Ferraz \& Segre (1997) que a saúde pode ser entendida como um estado de razoável harmonia entre o sujeito e a sua própria realidade.

Quanto à doença, percebe-se que “... é a falta de saúde, moléstia ou enfermidade" (Rocha \& Pires, 2000). Historicamente, foi entendida e interpretada de várias maneiras, com o passar dos anos e diante da multiplicidade de diferenças culturais.

Considerando-se que a saúde, na antiguidade, era considerada o estado em que o sangue, humor viscoso, bílis amarela e negra estavam em proporção correta, umas em relação às outras, tanto em força quanto em quantidade, a doença existia "quando uma dessas substâncias: o sangue o humor viscoso, a bílis amarela e 
negra" encontrava-se deficitária ou excedentária e encontra-se separada do corpo e nas misturas com as outras (Le Goff, 1997).

O termo inglês disease designa entidades mórbidas reconhecidas pela ciência médica, numa determinada época; illness remete para a forma como um indivíduo organiza as suas representações da doença, dos seus sintomas, da etiologia suposta do mal e da sua evolução; sickness designa a imagem da doença na sociedade (Le Goff,1997).

A situação entre o trabalho e a saúde/doença - constatada desde a antiguidade e exacerbada a partir da Revolução Industrial - nem sempre se constituiu em foco de atenção. Afinal, no trabalho escravo ou no regime servil, inexistia a preocupação em preservar a saúde dos que eram submetidos ao trabalho. Interpretado como castigo ou estigma: o tripalium era instrumento de tortura. $\mathrm{O}$ trabalhador, o escravo, o servo eram peças de engrenagens "naturais", pertences da terra, assemelhados aos animais e ferramentas, sem história, sem progresso, sem perspectivas, sem esperança terrestre, até que, consumidos seus corpos, pudessem voar livres pelos ares ou pelos céus da metafísica (Nosela, 1989).

“... Atualmente entende-se que melhorar a qualidade das condições de saúde no trabalho significa identificar os problemas, em cada situação, com a participação efetiva dos sujeitos do processo de trabalho e replanejá-lo, envolvendo para tal, um processo de negociação..." (Laurell \& Noriega 1989). 
A situação de trabalho nas instituições hospitalares apresenta-se problemática frente à inexistência de condições laborais satisfatórias, pelo fato de no hospital existir ambientes considerados insalubres, com pacientes de diversas patologias e fatores de risco outros, deletérios à saúde, o que acaba comprometendo a dos seus trabalhadores.

\subsection{A Enfermagem, seu trabalho e as suas categorias profissionais}

A enfermagem surgiu no século XIX, na Inglaterra, como prática para possibilitar a recuperação do indivíduo. Institucionalizou-se, no movimento do nascimento da clínica, juntamente com a transformação do hospital enquanto instrumento de cura (Almeida \& Rocha, 1997).

No Brasil, as atividades de assistência aos doentes iniciaram-se com o auxílio dos feiticeiros, pajés e curandeiros. Com a colonização portuguesa esses cuidados passaram a ser realizados pelos religiosos, voluntários, leigos e escravos selecionados.

A função peculiar da enfermagem é prestar assistência ao indivíduo sadio ou doente, família ou comunidade, no desempenho de atividades para promover, manter ou recuperar a saúde (Almeida e \& Rocha 1997).

É uma ação ou uma atividade realizada predominantemente por mulheres que precisam dela para reproduzir a sua própria existência; para isso, utilizam um saber advindo de outras ciências e de uma síntese produzida por elas próprias, para apreender o objeto de saúde naquilo que diz respeito ao seu campo específico, visualizando o produto final, que é atender as necessidades sociais, ou 
seja, a promoção da saúde, prevenção de doenças e a recuperação do indivíduo, ou o controle da saúde da população (Almeida \& Rocha 1997).

O pessoal de enfermagem cadastrado no Conselho Federal de Enfermagem (COFEN), até a atualidade, é estimado em 97968 enfermeiros, 126655 técnicos de enfermagem, 433824 auxiliares de enfermagem, 32492 atendentes de enfermagem e 562 parteiras (COFEN, 2002).

O Decreto $n^{\circ} 94.406$, de 08 de junho de 1987 , que regulamenta a Lei ${ }^{\circ}$ 7.498, de 25 de junho de 1986, dispõe sobre o exercício da enfermagem e dá outras providências (COREN - MG, 2001), explicita claramente sobre as categorias dessa profissão.

Assim, como técnico de enfermagem, a legislação considera: o titular do diploma ou de certificado de técnico de enfermagem, expedido de acordo com a legislação e registrado no órgão competente; o titular do diploma ou de certificado legalmente conferido por escola ou curso estrangeiro, registrado em virtude de acordo de intercâmbio cultural ou revalidado no Brasil como diploma de técnico de enfermagem. Esse trabalhador exerce as atividades auxiliares, de nível médio técnico, atribuídas à equipe de enfermagem, cabendo-lhe assistir ao enfermeiro no planejamento, programação, orientação e supervisão das atividades de assistência de enfermagem, na prestação de cuidados diretos de enfermagem a pacientes em estado grave, na prevenção e controle das doenças transmissíveis em geral em programas de vigilância epidemiológica, na prevenção e controle sistemático da infecção hospitalar, na prevenção e controle sistemático de danos físicos que possam ser causados aos pacientes durante a assistência de saúde, entre outras (COREN - MG, 2001). 
São auxiliares de enfermagem os titulares de certificado de auxiliar de enfermagem, conferido por instituição de ensino, nos termos da lei e registrado no órgão competente; o titular do certificado de enfermeiro prático ou prático de enfermagem, expedido até 1964, pelo Serviço Nacional de Fiscalização da Medicina e Farmácia, do Ministério da Saúde, ou por órgão congênere da Segurança de Saúde nas Unidades da Federação, nos termos do Decreto - Lei n ${ }^{\circ} 8.778$, de 22 de janeiro de 1946, e da Lei ${ }^{\circ}$ 3.640, de 10 de outubro de 1959; o pessoal enquadrado como auxiliar de enfermagem, nos termos do Decreto - Lei $\mathrm{n}^{0} 299$, de 28 fevereiro de 1967; o titular do diploma ou certificado conferido por escola ou curso estrangeiro, segundo as leis do país, registrado em virtude de acordo de intercâmbio cultural ou revalidado no Brasil como certificado de auxiliar de enfermagem (COREN - MG, 2001).

O enfermeiro é o titular do diploma de enfermeiro conferido por instituição de ensino, nos termos da lei; o titular do diploma ou certificado de obstetriz ou de enfermeira obstétrica, conferidos por lei; o titular do diploma ou certificado de enfermeiro e a titular do diploma ou certificado de enfermeira obstétrica ou de obstetriz, ou equivalente, conferido por escola estrangeira, segundo as leis do país, registrado em virtude de acordo de intercâmbio cultural ou revalidado no Brasil como diploma de enfermeiro, de enfermeira obstétrica ou de obstetriz (COREN - MG, 2001).

Considera-se ainda parteiro o titular do certificado previsto no artigo $1^{\circ}$ do Decreto-Lei $\mathrm{n}^{\circ} 8.778$, de 22 de janeiro de 1946, observado o disposto na Lei $\mathrm{n}^{\circ}$ 3.460, de 10 de outubro de 1959; o titular do diploma ou certificado de parteiro, ou equivalente conferido por escola ou curso estrangeiro, segundo as respectivas leis, 
registrado em virtude de intercâmbio cultural ou revalidado no Brasil até 26 de junho de 1988, como certificado de parteiro (COREN - MG, 2001).

O trabalho de enfermagem é realizado, então, por uma equipe ou grupo formado pelos trabalhadores de enfermagem anteriormente explicitados, sendo que, deles, apenas os enfermeiros possuem formação de nível superior nessa área.

Tendo o enfermeiro o papel de detentor do saber e de controlador do processo de trabalho da enfermagem, cabe aos demais trabalhadores de enfermagem a função de serem executores de tarefas delegadas (Leopardi et al,1999).

“... Até a um certo tempo atrás, confusos pela concepção idealizada da profissão, os trabalhadores de enfermagem não manifestavam os seus problemas, talvez por entendê-los como inerentes à mesma ou por percebê-los como resultados adversos decorrentes de alguma ação que não deveriam ter cometido e que poderia comprometer-lhes a competência profissional. Certamente os problemas ainda não são entendidos como situações decorrentes da maneira como é organizado o trabalho ou devido aos riscos ocupacionais presentes no ambiente laboral..." (Robazzi \& Marziale, 1999).

A enfermagem exerce papel central e de grande importância no atendimento ao paciente/cliente, estando assim exposta aos fatores de riscos, acidentes e doenças relacionadas ao trabalho, entre outras situações, pelo fato de 
permanecer maior parte de seu tempo ao lado do cliente e em contato íntimo com a insalubridade ambiental.

Ela é responsável pelo cuidado ao paciente/cliente, em toda a sua integralidade como ser biológico e social. É “cobrada" pelos médicos, pelos pacientes, por familiares e pela administração. No entanto, seu poder decisório é pequeno, depende de outros setores e regras de funcionamento da instituição que delimitam as suas possibilidades de ação (Leopardi et al, 1999).

\section{“...Recebendo formação diversificada, conforme a} categoria ocupacional a que pertencem, os trabalhadores de Enfermagem adoecem, acidentam-se em decorrência de seu trabalho e morrem. Nos dias de hoje já se começa a interrogar sobre a vida tão curta destes profissionais que vêm tentando lutar por melhores condições de higiene, saúde e segurança em seus ambientes laborais...” (Lopes, Spindola \& Martins, 1996).

Lopes, Meyer e Waldow, apud Guedes \& Mauro (2001, p.144), afirmam que a equipe de enfermagem deve modificar sua atitude frente ao trabalho, no sentido da formação da consciência acerca dos riscos ocupacionais nos locais onde executam atividades, em especial nos estabelecimentos da saúde, pois, por mais paradoxal que possa parecer, existe um descaso com a saúde do trabalhador de enfermagem no mesmo contexto em que esse promove o bem-estar físico e mental do paciente. 
Sabe-se que é uma constante esse descaso, entretanto, percebe-se que o próprio trabalhador não se protege e despreocupa-se com a sua própria saúde, possivelmente porque desconhece os fatores de riscos ocupacionais e existem algumas situações que o deixam desestimulado, tais como a baixa remuneração, a insatisfação no trabalho pela falta de realização pessoal, as condições inadequadas de trabalho, podendo aumentar a sua exposição aos riscos, possibilitando o acontecimento de acidentes de trabalho e/ou enfermidades.

Observa-se ainda a existência de certa competitividade no trabalho de enfermagem, em que cada profissional tende a mostrar o seu trabalho como sendo o melhor, esquecendo-se de algumas prioridades que deveriam fazer parte do seu cotidiano, como o lazer, o convívio em família, o relacionamento entre os colegas, chefias e o paciente, favorecendo assim o aumento do estresse da sua atividade.

Assim sendo, faz-se necessário que os trabalhadores de enfermagem sejam estimulados a desenvolver suas atividades em condições adequadas de trabalho, participando de um processo de educação continuada.

\subsection{Riscos ocupacionais relacionados ao trabalho de enfermagem}

Os fatores ou agentes de riscos químicos, físicos, biológicos e ergonômicos são considerados os principais responsáveis pelas situações insalubres e de periculosidade a qual os profissionais de enfermagem encontram-se expostos (Bulhões, 1994). 
“... O risco pode ser considerado um perigo ou a possibilidade de perigo...” (Ferreira, 2001). “...Significa um perigo e probabilidade ou possibilidade de existir o dano ou perigo..." (Rocha \& Pires, 2000).

É todo o fator ambiental que pode ocasionar lesão, doença ou inaptidão ou afetar o bem-estar dos trabalhadores (Burguess, 1997). Dessa forma, as substâncias químicas tóxicas, as poeiras, o ruído, a vibração, o calor ou o frio excessivo, as radiações, os microrganismos, as posturas viciosas do trabalho, a tensão, os movimentos repetitivos e a monotonia que acontece em decorrência do trabalho são considerados riscos ocupacionais ou "cargas de trabalho", segundo a expressão utilizada por Laurell \& Noriega (1989).

Risco ocupacional é toda a situação encontrada no ambiente de trabalho, que representa perigo a integridade física e/ou mental dos trabalhadores (Vieira, 1996).

A Norma Regulamentadora (NR) 5, elaborada e divulgada pelo Ministério do Trabalho e Emprego, estabelece que esses riscos constituem-se em todas as situações que podem trazer ou ocasionar danos à saúde do trabalhador no ambiente de trabalho, podendo trazer conseqüências em curto, médio e longo prazo, isto é, provocar vários tipos de seqüelas, desde as imediatas, denominadas agudas, até as tardias, chamadas crônicas (BRASIL, 2001).

No ambiente de trabalho, o risco ocupacional pode ser ou estar oculto por ignorância, falta de conhecimento ou de informação, situação em que o trabalhador sequer suspeita de sua existência. Pode também se encontrar latente, 
situação em que o risco só se manifesta e causa danos em situações de emergência ou condições de estresse; o trabalhador sabe que está "correndo riscos", mas as condições de trabalho o forçam a isso; também o risco pode ser real - conhecido de todos, mas sem possibilidade de controle, quer por inexistência de solução para tal, quer pelos altos custos exigidos, quer, ainda, por falta de vontade política (Bulhões, 1994).

Os estabelecimentos de assistência à saúde, de modo geral, e entre eles o hospital, possuem elevado grau de complexidade, no que se refere à distribuição de atividades, grau de permanência das pessoas, uso dos espaços, categorias de usuários; é um local que agrega a convivência de pacientes (externos e internos), trabalhadores da saúde, visitantes e pessoal de apoio (Oliveira e Ribas, 1995).

No ambiente hospitalar, a preferência ou prioridade é dada ao conforto e segurança do usuário-paciente. No entanto, o universo de trabalhadores que aí se agregam pode sofrer alterações de saúde, diante dos numerosos agentes existentes e do tempo e intensidade do contato entre tais pessoas e esses agentes.

Sendo assim, os fatores de risco do trabalho podem ser classificados de acordo com o tipo de agente envolvido. Para efeito da NR 9, que trata do Programa de Prevenção de Riscos Ambientais (PPRA), considera-se como riscos ambientais os agentes físicos, químicos e biológicos existentes no ambiente de trabalho (Brasil, 2001).

Os riscos ocupacionais, particularmente os existentes em hospitais, já foram objeto de vários estudos, entre os quais pôde ser apreendido que eles acontecem em decorrência de agentes biológicos, físicos, químicos e ergonômicos, presentes nesse ambiente de trabalho (Reis, 1986; Lima, 1987; Costa \& Deus, 1989; 
Praça \& Grandi, 1989; Bulhões, 1994; Marziale, 1995; Avendaño et al, 1995; Santos, 1996; Takeda, 1996; Benatti, 1997; Meirelles, 1997; Alexandre, 1998; Fariño Gabino, 1998; Retamar, 1998; Rodrigues, 1998; Roberts et al, 1999; Suazo, 1999; Shigueno, 2000; Marziale et al. 2000; Monteiro, 2001).

São considerados os vários agentes capazes de ocasionar problemas à saúde do trabalhador, considerando-se a sua natureza, concentração ou intensidade e tempo de exposição.

Sabe-se que os mecanismos reguladores do metabolismo, em situações principalmente em que a saúde encontra-se abalada, diante de determinadas condições ambientais, tornam-se debilitados, o que, evidentemente, acaba favorecendo o adoecimento dos que permanecem nesses ambientes (Oliveira e Ribas, 1995), que é o caso particular da equipe de enfermagem, realizadora de um trabalho que perdura durante 24 horas.

Alguns dos agentes físicos concentram-se sob a denominação de riscos físicos, que no ambiente de trabalho hospitalar estão representados pelas radiações ionizantes (raios X, raios gama, beta), não ionizantes (ultravioleta, infravermelho, microondas e raio laser), ruídos, vibrações, pressões anormais, temperaturas, eletricidade e iluminação (Guidotti, 1987; Tan, 1991; Marziale, 1995; Benatti, 1997; Bulhões, 1998; Brasil, 2001, Benavides, 2002; Mendes, 2003).

“... Entre os riscos físicos presentes no ambiente hospitalar encontra-se a temperatura ambiental excessiva nas áreas de esterilização ou abaixo do normal em locais onde as aparelhagens assim o exige; as radiações ionizantes 
comuns nos serviços de radiologia, radioterapia $e$ manipulação de radioisótopos; as radiações não ionizantes presentes nos raios ultravioletas, infravermelho, laser $e$ microondas; os ruídos externos e internos; a iluminação nem sempre adequada e suficiente, entre outros problemas..." (Silva, 1998; Marziale, 1995; Bulhões, 1994; 1998).

A Organização Internacional do Trabalho (OIT) considera como principais fatores de risco físico para os trabalhadores de saúde as radiações ionizantes, o ruído, a temperatura e a eletricidade (Bulhões, 1994).

Entende-se que os agentes de risco físico possuem materialidade externa ao corpo humano e podem ser detectados e também medidos. Algumas doenças relacionadas ao trabalho podem ser ocasionadas por ação desses agentes; entretanto, os limites da ação dos mesmos, são, muitas vezes, imprecisos. Sabe-se que, muitas vezes, associam para determinarem o aparecimento de agravos à saúde (Binder et al, 1995).

Os vários parâmetros do ambiente físico criam determinadas qualidades ambientais que são percebidas e avaliadas pelo homem. Assim, os parâmetros e os níveis de iluminação, distribuição da luminância, a cor e a sua avaliação criam a qualidade da iluminação; a velocidade do ar, a sua temperatura, a temperatura radiante e a sua umidade propiciam o balanço térmico do corpo; os componentes desejáveis do ar e a sua poluição criam a sua qualidade; o nível de pressão do som, a distribuição da freqüência e a variação no tempo proporcionam a qualidade do som. 
O ser humano consegue realizar uma avaliação integrada dessas qualidades ambientais (Oliveira \& Ribas, 1995).

No entanto, em muitas situações, dependendo possivelmente do quanto já se acostumou com tais qualidades ambientais, a percepção e a conseqüente avaliação, tornam-se inoperantes, o que leva o homem a submeter-se aos riscos, sem o desejar. Acredita-se que situações dessa natureza, em que o indivíduo deixa de perceber os vários fatores ambientais, favorecem o seu adoecimento em decorrência da exposição aos mesmos.

Discorrendo, particularmente sobre os agentes físicos, tem-se a vibração. Corresponde ao ato de vibrar, que, por sua vez, significa agitar, fazer tremular ou oscilar, fazer soar, comunicar vibrações, pulsar, ter som claro e distinto, ecoar (Rocha \& Pires, 2000).

“... O fenômeno vibratório é caracterizado pela oscilação de um corpo sólido em torno de uma posição de referência. Tal fenômeno pode ser do tipo determinístico, caso apresente um andamento bem definido no tempo e, portanto, previsível, ou do tipo aleatório, como no caso das exposições encontradas nas situações de trabalho...” (Silva, 2003).

Os componentes que definem a vibração são a magnitude, a freqüência, a duração e a direção. A grande maioria das normas adota a aceleração como o meio para quantificar a magnitude da vibração, uma vez que é um procedimento mais 
conveniente. O Sistema Internacional de Medidas adota a quantificação da aceleração em $\mathrm{m} / \mathrm{s}^{2}$ (metros por segundo ao quadrado). A aceleração em m/s $/ \mathrm{s}^{2} \mathrm{r}, \mathrm{m}, \mathrm{s}$ (root-mean-square) é geralmente eleita como o método preferido para quantificar a importância da exposição à vibração. A sua freqüência é avaliada pelo movimento periódico que se repete igualmente em um intervalo de tempo, denominado período. A freqüência do movimento é fornecida pelo inverso do período e, portanto, pode ser expressa como um número de ciclos do movimento por segundo. A medida da freqüência em ciclos por segundo $(c, p, s)$ é chamada Hertz. A duração da vibração está associada com determinadas respostas humanas à mesma. A magnitude da aceleração pode ser influenciada pela duração da medição da vibração. A resposta do corpo à vibração depende de sua direção e a região do corpo atingida (Mendes, 2003).

Estudos nacionais e internacionais mostram os efeitos da vibração sobre o corpo e a saúde humana (Klingenstierna \& Pope, 1987; Carnicelli, 1994; Acgih, 1999). Esses efeitos manifestam-se desde dor de cabeça, insônia, esquecimento, irratibilidade, depressão, zumbido e impotência, até perda auditiva, nistagmo e vertigem. Essas alterações são observadas em 60 a 70\% dos indivíduos expostos à vibração através das mãos (Matoba, 1994). Em indivíduos expostos à vibração de corpo inteiro ocorre complexa distribuição de movimentos oscilatórios e forças dentro do organismo, podendo existir grande variação de queixas e intensidade delas em relação aos efeitos biológicos por ela causados. A vibração pode causar sensação de desconforto e mau humor, influenciar o desempenho ou oferecer risco à saúde e segurança. 
A exposição às vibrações pode trazer efeitos variados para a saúde do trabalhador como: visão turva, perda do equilíbrio, mal estar, falta de concentração, fadiga e diminuição do rendimento (Benavides, 2000).

Os efeitos danosos das vibrações podem acometer pessoas (funcionários e pacientes), as estruturas da edificação, assim também como os equipamentos sensíveis, cujo efeito impede o seu adequado funcionamento. Em paciente, os seus efeitos danosos podem ser percebidos em técnicas de terapia como o ultra-som terapêutico e a litotripsia (ANVISA, 2002).

Quanto ao calor, é um fenômeno físico que determina a elevação da temperatura; é a qualidade do que é quente (Rocha \& Pires, 2000). É uma forma de energia que pode ser transmitida de um corpo para outro, por radiação, condução ou convecção. A quantidade dessa energia (recebida ou entregue) é determinada pela variação de temperatura do corpo que a cedeu ou a recebeu (ANVISA, 2002).

É contemplado na legislação brasileira atual, na NR 17, a qual recomenda que "nos locais de trabalho onde são executadas atividades que exijam solicitação intelectual e atenção constante, tais como salas de controle, laboratórios, escritórios, salas de desenvolvimento ou análise de projetos, dentre outros, são recomendadas as seguintes condições de conforto: níveis de ruído de até $65 \mathrm{~dB}$ (decibéis); índice de temperatura efetiva entre 20 a $23^{\circ} \mathrm{C}$; velocidade do ar não superior a $0,75 \mathrm{~m} / \mathrm{s}$ (metros por segundo) e umidade relativa do ar não inferior a 40\%” (Santos Junior, 2003).

A transmissão por radiação ocorre através de ondas eletromagnéticas, que transmitem através do ar e do vácuo. Por radiação, a transmissão de calor acontece pelo contato direto entre as partes que recebem e aquelas que o cedem; por 
convecção, ocorre através das massas de ar que, ao se aquecerem, diminuem sua densidade, de tal sorte que se tornam mais leves, sobem, dando lugar às massas de ar mais frias que as primeiras ( ANVISA, 2002).

“... O calor é largamente utilizado no ambiente hospitalar, nas operações de limpeza, desinfecção e esterilização dos artigos e áreas hospitalares. É empregado, ainda, com finalidade terapêutica como nos casos de berços aquecidos e incubadoras utilizadas nos tratamentos de recém-nascidos; em equipamentos de diatermia, que adotam o uso de radiofreqüência para produção de calor em tecidos vivos; unidades eletrocirúrgicas ou raios "laser" empregados em sofisticadas técnicas cirúrgicas, visando de modo geral o corte e coagulação dos tecidos humanos. $O$ funcionário no ambiente hospitalar está sujeito a fontes de calor nos seguintes ambientes: centro de esterilização de materiais, serviços de nutrição e dietética, lavanderia hospitalar e casa de caldeiras. No centro de esterilização de materiais, as fontes de calor são provenientes de estufas $e$ autoclaves. Estas utilizam o calor na forma de vapor saturado e na forma seca..." (ANVISA, 2002).

O trabalho em exposição ao calor é mais freqüente do que o exercício em baixas temperaturas; o organismo procura defender-se das temperaturas 
elevadas, principalmente por condução e temperatura excessiva. A sudorese é dificultada quando o grau higrométrico do ambiente é elevado (Araújo, 1994).

“... Além disso, há que se considerar que fatores vários concorrem para a dificuldade na luta contra o calor, como a saturação da atmosfera por umidade, a falta de movimentação do ar, a ausência dos vestuários adequados, entre outros. Quando os meios comuns de defesa contra o calor são colocados em prática, inclusive a compensação do organismo pela perda de água e sal eliminados pela sudorese, é possível haver a prevenção dos sintomas dos acidentes hipotérmicos, tais como cãibras, proteção térmica, insolação, golpe de calor, entre outros...” (Araújo, 1994).

Quanto à iluminação, Rocha \& Pires (2000) a entendem como o ato de iluminar, o conjunto de luzes. Informam também que o gás de iluminação, descoberto por Lebon, em 1799, só começou a ser usado, na prática, em 1805.

“... No ambiente de trabalho uma boa iluminação propicia elevada produtividade, melhor qualidade do produto final, redução do número de acidentes, diminuição do desperdício de materiais, redução da fadiga ocular e geral, melhor supervisão do trabalho, maior aproveitamento do espaço, mais ordem, e limpeza das áreas e elevação da moral 
dos funcionários. Para o caso do ambiente hospitala,r a questão da iluminação deve ser, principalmente, enfocada nas salas e cirúrgicas e no campo operatório. A má iluminação nestes casos pode acarretar em graves prejuízos ao profissional e ao paciente. Para diminuir os riscos nas salas de cirurgia, a alimentação elétrica de focos deve ser feita com 24 volts. A adequação da iluminação nas salas de tricotomia também contribui muito para a redução de acidentes nesse processo de preparo do paciente para intervenções cirúrgicas ou mesmo em simples exames de eletrocardiografia. O reconhecimento do risco se faz com a declaração dos trabalhadores relativos à”. iluminação do ambiente de trabalho. Pode ser feito, também, pela investigação e análise de acidentes ocorridos por iluminação deficiente, pela verificação de áreas sombreadas nos locais de trabalho, entre outras..."(ANVISA, 2002).

“... A boa luz facilita não somente a visão, mas estimula também o prazer no trabalho e o bem-estar, aumentando a capacidade de concentração e evitando a estafa precoce. A visão facilitada, o bem-estar e ativação pela luz conduzem a um melhor desempenho no trabalho, reduzindo o número de erros, as quebras de produção e os acidentes...” (Vieira, 1998). 
Por radiação é entendido o ato de radiar, a designação das diversas formas ondulatórias, sob as quais a energia pode ser transmitida ao espaço (Rocha \& Pires, 2000).

As radiações ionizantes são representadas pelos raios $\mathrm{X}$, raios gama, raio beta, partículas gama, prótons e nêutrons, que são familiares em locais como radiologia, radioterapia e manipulação dos radioisótopos. As não ionizantes podem ser representadas pelos raios ultravioleta, infravermelho, microondas e laser (Silva, 1988; Marziale, 1995; Bulhões, 1994, 1998, Valverde, 2003).

“...As radiações ionizantes são aquelas capazes de ionizar a matéria com a qual interagem. Os efeitos biológicos que as radiações produzem podem ser somáticos ou hereditários. Os primeiros são aqueles que podem se manifestar no próprio indivíduo que recebeu a dose; os efeitos hereditários podem se manifestar nos descendentes do indivíduo que recebeu a dose (Vieira, 1998).

As radiações de efeitos hereditários são aquelas que produzem lesões nas células germinativas da pessoa irradiada, as quais são transmitidas aos seus descendentes. As de efeitos somáticos produzem lesões nas células do indivíduo que foi irradiado, entretanto, tais lesões não são transmitidas hereditariamente. $\mathrm{Na}$ área hospitalar, os riscos inerentes às radiações ionizantes relacionam-se às áreas de radioproteção e radioterapia. Esses riscos também estão presentes em outras áreas, 
utilizam equipamentos de diagnóstico e de imagens médicas em tempo real, como centros cirúrgicos e unidade de terapia intensiva (ANVISA, 2002).

"Deve-se ter em mente que os efeitos biológicos de qualquer índole, consequentemente à irradiação, têm origem na lesão do ADN (ácido Desoxirribonucléico)” (Valverde, 2003).

Nenhum trabalhador deveria se expor às radiações ionizantes sem que seja necessário; além disso, ele deve ter conhecimento dos riscos radiológicos associados ao seu trabalho; estar adequadamente treinado para o desempenho seguro de suas funções; estar utilizando os Equipamentos de Proteção Individual (EPI) necessários à prevenção dos riscos aos quais está exposto, entre outros.

“... Quanto às radiações eletromagnéticas não ionizantes (RNI) são as que não possuem energia para produzir ionização de átomos ou moléculas. As radiações não ionizantes são classificadas em: ondas longas, médias e curtas, usadas em radiocomunicação e diatermia; ondas ultracurtas usadas em televisão; microondas usadas em telefonia, radar e aquecimento (doméstico e industrial); infravermelho, presente em metais aquecidos; luz visível de lâmpadas incandescentes e fluorescentes; ultravioleta de uso médico e industrial...” (Duca, 2003). 
As radiações não - ionizantes apresentam, como efeitos imediatos, a partir de doses excessivas, irritação da conjuntiva ocular, da córnea e lesão de retina. A exposição crônica às radiações ultravioletas contribui para o envelhecimento dérmico prematuro, cataratas e câncer de pele. Os efeitos térmicos sobre os tecidos em exposição prolongada podem produzir um desequilíbrio do sistema de termorrregulação, denominado "golpe do calor" que pode ser mortal. (Benavides, 2000).

Os efeitos para a saúde do trabalhador são variados e demonstrados por diversos estudos (Jones, et al, 1987; McAbee, Gallucci \& Checkoway, 1993; Li et al, 1995; Rozgajk, Kasuba \& Peric, 1999; Cunha \& Drexler, 1992).

Normalmente define-se o ruído como sendo um som inadequado. Explicam Rocha \& Pires (2000) que é o rumor produzido por um corpo que cai, que estala, que se atrita; barulho, estrondo.

"Ruído ou barulho pode ser definido como som desagradável ou indesejado propagado num meio elástico como ar, água e sólido”. (Fischer et al, 1989).

Conforme o American National Standards Institute (ANSI), em 1994, apud NIOSH (1998), o ruído consiste em um som errático, intermitente ou com oscilação estatisticamente aleatória. Por sua vez, som representa uma sensação auditiva provocada por variações de pressão geradas por alguma fonte de vibração (Smith \& Peters, 1992). 
É um agente fortemente predominante em uma variedade de atividades econômicas, sobretudo nas indústrias. Do ponto de vista da metodologia de observação, pode ser classificado nos tipos que se seguem: o contínuo que apresenta flutuações pequenas e desprezíveis de nível no período de observação. Pode ser encontrado em indústrias têxteis em seções de teatros, fiatórios e outras máquinas similares. O ruído intermitente é aquele cujos níveis são interrompidos por intervalos de níveis sonoros relativamente baixos (NIOSH, 1998), com variação previsível, é originário de fontes sonoras constantes ou periódicas de número limitado. Há ainda o ruído variável com ou sem tons audíveis, no qual o nível varia substancialmente durante o período de observação. Tal tipo de ruído manifesta-se em caldeireiras e outras indústrias do ramo metal-mecânico, onde são executados trabalhos de soldagem, esmerilhamento, lixamento e martelamento de chapas, entre outros (Silva, 2003).

Nos ambientes hospitalares, as áreas que estão expostas aos níveis de ruído elevados são as centrais de compressão de ar e geração de vácuo, as oficinas de manutenção e as centrais de geração de energia elétrica. Porém, nas unidades de tratamento intensivo existem ruídos de menor intensidade, que podem se tornar incômodos devido aos alarmes sonoros presentes nos equipamentos (ANVISA, 2002).

Há que se considerar também o importante ruído que acontece em setores como as lavanderias, por exemplo.

O ruído pode trazer sérias perturbações funcionais ao organismo. Afeta o sistema nervoso, o aparelho digestivo e circulatório, traz desconforto e fadiga. As conseqüências mais imediatas são: redução transitória da acuidade auditiva que 
ocorre nos casos de exposição nos níveis de ruídos variando entre 90 a 120 dB, durante períodos de tempo relativamente curtos (minutos, horas ou dias) e surdez profissional, em casos de exposição relativamente prolongada (meses ou anos) de indivíduos suscetíveis a ruídos intensos (90 a 120 dB). A avaliação ambiental deve ser feita utilizando-se um decibelímetro (medidor de pressão sonora). O instrumento deverá ser posicionado de modo a receber o ruído que atinge o ouvido do trabalhador (ANVISA, 2002).

Vários autores estudaram os seus efeitos negativos à saúde (Santana \& Barberino, 1995; Teixeira, Cleide Fernades, Augusto, \& Morata, 2003; Corrêa Filho et al, 2002; Leme, 2001; Zannin, \& Szeremetta, 2003; Cunha, et al, 1998). No estudo de Leme (2001) constatou-se que, após a avaliação audiométrica em 61 trabalhadores de um hospital público de São Paulo, expostos ao ruído habitual no seu ambiente de trabalho nas áreas de laboratório clínico, marcenaria, mecânica, serralheria e telefonia, comparados a um grupo controle de 30 pessoas, não expostos ao ruído de maquinário, encontrou perda auditiva superior à esperada.

Informa a Norma Brasileira (NBR) 10152, que fixa os níveis de ruído compatíveis com o conforto acústico nos diversos ambiente, que, nos hospitais, os valores de ruído medidos, em decibéis variam de 35 a 45 em apartamentos, enfermarias, berçários e centros cirúrgicos; 40 a 50 em laboratórios e áreas para uso do público, e 45 a 55 em áreas de serviços. Considera-se que o valor inferior de cada um desses intervalos representa o nível sonoro para conforto, enquanto que o valor superior significa o nível aceitável para aquela finalidade. Níveis superiores aos mencionados são tidos como de desconforto (Associação Brasileira das Normas Técnicas, 1987). 


\begin{abstract}
“... Habitualmente, os níveis de ruído existentes nos hospitais são inferiores aos tidos como perturbadores. Esta perturbação pode reduzir a eficiência das comunicações entre os profissionais e impedir o descaso e a reabilitação dos pacientes, em fase de recuperação...” (ANVISA, 2002).
\end{abstract}

Rocha \& Pires (2000) definem umidade como sendo qualidade ou estado de úmido.

A umidade excessiva no ambiente hospitalar não é comum, embora possa ser encontrada em construções cujos projetos originais foram mal concebidos ou por influência do meio externo. As lavanderias, devido às atividades de higiene $\mathrm{e}$ limpeza, são os locais onde mais se faz uso de água dentro do ambiente hospitalar, São ambientes onde facilmente é reconhecida a umidade. É detectada através de inspeção visual, identificando manchas nas paredes e pisos, decorrentes de infiltrações de água. A umidade presente no ar deve ser avaliada através de equipamentos específicos, como o termo-higrômetro (ANVISA, 2002).

Isso posto, o presente estudo objetiva investigar entre a categoria de auxiliares de enfermagem, alguns aspectos relacionados aos fatores que os predispõem aos riscos ocupacionais físicos, provocando-lhes alterações à saúde. 


\section{METODOLOGIA}

O presente estudo é seccional, não-experimental, de caráter descritivo, utilizando a análise quantitativa dos dados e foi direcionada a partir dos conceitos descritos na literatura por Polit \& Hungler (1995).

\subsection{Campo do estudo}

A pesquisa foi realizada na cidade de Uberaba, Estado de Minas Gerais em um Hospital Escola (HE) que desenvolve atividades de ensino e pesquisa. É uma entidade autárquica federal, mantida por verbas federais e por recursos da Fundação de Ensino e Pesquisa de Uberaba (FUNEPU).

Possui 306 leitos e inclui atendimento de Clínica Médica, Clínica Cirúrgica, Unidade de Infecção Hospitalar (UIH), Unidade de Terapia Renal (UTR), Centro de Terapia Intensiva Adulto (CTIA), Centro de Terapia Intensiva Pediátrico (CTIP), Ortopedia, Neurologia, Unidade de Terapia Intensiva Coronariana, Pediatria, Pronto Socorro Adulto e Pronto Socorro Infantil.

O HE presta assistência aos níveis secundário e terciário, servindo como campo de ensino e estágio para graduandos de medicina, enfermagem, biomedicina e cursos de ensino médio como radiologia, técnico de enfermagem, técnico em patologia, técnico em nutrição, dentre outros. 


\subsection{Sujeitos da pesquisa}

Para participar do estudo, buscou-se os auxiliares de enfermagem, por constituir a categoria de trabalhadores de enfermagem mais numerosa.

O quadro de trabalhadores de Enfermagem, no referido hospital, era composto por 53 (cinquenta e tres) enfermeiros, 258 (duzentos e cinquenta e oito) auxiliares de enfermagem e 83 (oitenta e tres) técnicos de enfermagem, na ocasião da coleta de dados (julho - agosto de 2003).

A população foi constituída por auxiliares de enfermagem, que fizessem parte do quadro funcional representativo da categoria no HE no período da coleta de dados, atendendo aos seguintes critérios de inclusão no estudo: pertencer à categoria profissional de auxiliar de enfermagem do HE; ser de ambos os sexos; consentir em participar da pesquisa; não estar de férias e estar trabalhando sem qualquer tipo de restrição como licenças; comparecer ao local de trabalho no período estabelecido para a coleta de dados, nos diferentes turnos laborais.

O grupo estudado constituiu-se então de 85 (oitenta e cinco) auxiliares de enfermagem, dado que no momento da coleta de dados constatou-se que: 30 (trinta) encontravam-se de férias, 14 (catorze) estavam de licença-saúde, 6 (seis) não eram do HE e faziam parte de outra instituição, estando emprestados para o referido hospital; outros recusaram-se a participar do estudo, manifestando estar muito atarefados e sem interesse em tal participação. É preciso acrescentar que neste período aconteceu uma greve, sendo que $6 \%$ dos auxiliares aderiram a mesma.

Houve dificuldade, por parte da pesquisadora, em proceder a coleta de dados, pois muitas vezes, mesmo com horário previamente marcado, chegava para 
conversar com o trabalhador e este encontrava-se ocupado; quando o horário era remarcado, em muitas ocasiões aconteceu da coleta não ter sido feita, porque os trabalhadores alegavam também não terem tempo atendê-la, por vários motivos declarados naquele instante. Como o HE é um hospital de ensino e pesquisa, muitos trabalhadores demonstraram cansaço porque, continuamente, respondiam aos questionamentos ou eram entrevistados com a finalidade de participarem de pesquisas. Ou seja, houve certa indisponibilidade dos sujeitos em participar da pesquisa, bem como a acessibilidade dificultada, fatores esses que interferiram no total de pessoas a serem entrevistadas.

\subsection{Procedimentos metodológicos}

Foi utilizado para a coleta de dados um questionário, apresentado no Anexo 1, que constou dos dados biográficos e profissionais dos auxiliares de enfermagem e foi aplicado através da técnica de entrevista. $\mathrm{O}$ instrumento continha ainda perguntas fechadas e abertas com vistas a obter informações sobre os problemas de saúde desses trabalhadores, sendo previamente apreciado por três enfermeiros pesquisadores, que opinaram quanto ao seu conteúdo, clareza e objetividade. Antes da coleta de dados, foi aplicado também a 7 (sete) auxiliares de enfermagem, não pertencentes ao $\mathrm{HE}$, com a finalidade de analisar as suas dificuldades quanto às questões, ajustando-as, a partir de suas sugestões.

Os dados foram coletados pela própria pesquisadora durante os meses de julho a agosto de 2003. Encerrada a fase de coleta, foram digitados em banco de dados do programa Epi Info/97. 
A análise dos dados foi realizada através dos programas Excel/97. Para avaliar e agrupar as alterações de saúde referenciadas pelas auxiliares de enfermagem foi utilizado a Classificação Internacional de Doenças e Problemas Relacionados à Saúde (CID - 10) de 1993.

\subsection{Autorização e aspectos éticos}

Para realização da pesquisa, foi solicitada a prévia permissão da Diretora de Enfermagem do HE, para a qual foi encaminhado o presente estudo em forma inicial de projeto de pesquisa, anexado a uma carta solicitando-lhe a autorização. Esta foi concedida e encontra-se no Anexo 2.

Após a autorização, o projeto foi encaminhado ao Comitê de Ética em Pesquisa da Universidade de Uberaba para a devida aprovação, o que aconteceu em julho de 2003 (Anexo 3). Como implica em pesquisa envolvendo seres humanos, a fim de contemplar as exigências da Portaria 196, que normatiza esse tipo de pesquisa, todos os trabalhadores foram informados sobre a sua natureza, seus objetivos, métodos, benefícios previstos, potenciais riscos e incômodos que essa poderia provocar. Elaborou-se um termo de consentimento (Anexo 4), autorizando a participação voluntária dos trabalhadores na pesquisa (Brasil, 1996). O Consentimento, após o Esclarecimento, encontra-se apresentado no Anexo 5. 


\section{Apresentação e discussão dos dados}

Os resultados do presente estudo encontram-se distribuídos em tabelas acompanhadas da discussão subsidiada pelas evidências descritas na literatura.

Os dados biográficos, dos 85 sujeitos, encontram-se apresentados, na Tabela 1.

Tabela1- Distribuição de auxiliares de enfermagem de um Hospital Escola segundo o sexo, estado civil, idade e o grau de escolaridade. Uberaba, MG, $2003(n=85)$

\begin{tabular}{llrc}
\hline Variáveis & & $\mathbf{n}$ & $\%$ \\
\hline Sexo & Masculino & 15 & 17,7 \\
& Feminino & 70 & 82,3 \\
\hline Total & & 85 & 100 \\
\hline Estado Civil & Solteiro & 30 & 35,3 \\
& Casado & 35 & 41,2 \\
& Separado & 10 & 11,8 \\
& Divorciado & 6 & 7,1 \\
& Viúvo & 3 & 3,5 \\
& Amasiado & 1 & 1,1 \\
\hline Total & & 85 & 100 \\
\hline Idade & $21-j 3$ & 17 & 20,0 \\
& $31-40$ & 23 & 27,1 \\
& $41-j 0$ & 17 & 20,0 \\
& $>50$ & 8 & 9,4 \\
& Sem resposta & 20 & 23,5 \\
\hline Total & & 85 & 100 \\
\hline Escolaridade & Ensino fundamental & 17 & 20,0 \\
& Ensino médio & 51 & 60,0 \\
& Nível Superior Completo & 5 & 5,9 \\
& Nível Superior Incompleto & 10 & 11,8 \\
& Sem resposta & 2 & 2,3 \\
\hline Total & & 85 & 100 \\
\hline
\end{tabular}


A maioria dos entrevistados $(82,3 \%)$ pertencia ao sexo feminino, sendo essa a realidade da enfermagem do hospital investigado, encontrada também por outros estudiosos da profissão, como Aquino et al (1993), Santos et al (1993), Bulhões (1994), Marziale (1995), Lopes Et al (1996), Takeda (1996), Benatti (1997), Jansen (1997), Tonhom (1997), Miranda (1998 a), Marziale (1999), Silva (1999), Napoleão (1999), Rojas (1999), Robazzi \& Marziale (1999), Suazo \& Robazzi (2000), Nicolete (2001), Monteiro (2001), Elias (2002), Rocha (2002), Barbin (2003).

Aquino et al (1993) afirmam, a partir de dados fornecidos por Médici et al em 1987 que, até 1970, a participação feminina na força de trabalho em saúde era pequena, ainda que algumas categorias profissionais fossem tradicionalmente ocupadas por mulheres, dentre as quais enfermagem. Na década de 70, acompanhando a tendência observada no conjunto da população economicamente ativa, essa participação aumentou de 41 para $63 \%$, chegando, na década de 80 com a hegemonia feminina no setor.

A predominância de mulheres na enfermagem é histórica, pois o cuidado aos pacientes parece sempre ter sido efetuado por mulheres religiosas, viúvas, virgens e nobres, com o objetivo de realizar caridade. Hoje essa situação ainda é mantida, embora outras profissões da área da saúde estejam também demonstrado interesse pelo cuidar e muitas das mulheres da enfermagem parecem, em sua gênese, apresentar a vocação para a escolha dessa árdua profissão.

Em relação ao estado civil, $41,2 \%$ dos sujeitos eram casados, $35,3 \%$ solteiros; os demais $(11,8 \%)$ eram separados, $7,1 \%$ divorciados, $3,5 \%$ viúvos e $1,1 \%$ amasiado. Essas informações não diferem muito dos dados de 1983, mostrados no 
estudo da ABEn/COFEN (1985), pois naquela época também observou-se, tal como atualmente, uma divisão bastante equilibrada entre solteiros e casados $(45,3$ e 42\%, respectivamente), além de menores percentuais entre viúvos $(2,5 \%)$ e separados $(9,4 \%)$.

A idade variou entre 21 e 57 anos, sendo a média etária de 31 anos. Comparada à idade dos auxiliares de enfermagem estudados pelo ABEn/COFEN (1985) no ano de 1983, constatou-se que havia também, na época, predominância desses trabalhadores no grupo de idade de 30 a 34 anos, seguido daqueles que tinham idade entre 35 e 39 e 25 e 29 anos.

O estudo de Santos et al (1993), que investigou os fatores predominantes de acidentes de trabalho na área de enfermagem em um hospital do Rio de Janeiro RJ, evidenciou, entre os auxiliares de enfermagem, que a maioria $(54,5 \%)$ dos sujeitos estudados situava-se na faixa etária de 18 a 39 anos.

Analisando-se os dados em relação à escolaridade, constata-se que $60 \%$ dos sujeitos do presente estudo concluíram o segundo grau e $20 \%$ possuíam o primeiro grau completo, o que é esperado diante da exigência curricular para a formação desse nível ocupacional da enfermagem. Evidencia-se que 5,9\% dos auxiliares possuíam nível superior completo e 11,8\% estavam cursando faculdade e, mesmo assim, ainda continuavam exercendo as atividades como auxiliares de enfermagem.

Percebe-se o interesse dos trabalhadores em ascender tanto pessoalmente quanto no âmbito profissional. No estudo da ABEn/COFEN (1985), constatou-se que, em 1983, 39,9\% desse pessoal possuía ou estava cursando o ensino fundamental; 51,8\%, o ensino médio e 8,2\%, o curso superior. Na presente 
investigação, contabilizando-se aqueles do ensino médio com os do ensino fundamental, torna-se claro que $80 \%$ desses trabalhadores encontravam-se em consonância com o que se espera deles, ou seja, possuíam, no mínimo, o primeiro grau.

Para apresentação dos dados profissionais foi elaborada a Tabela 2 que se segue.

Tabela 2: Distribuição de auxiliares de enfermagem de um Hospital Escola segundo as horas trabalhadas por semana, a existência de outro emprego e o setor de trabalho. Uberaba, MG, 2003, $(n=85)$.

\begin{tabular}{lccc}
\hline Variáveis & & $\mathbf{n}$ & $\mathbf{\%}$ \\
\hline Horas trabalhadas por semana & & & \\
& 36 horas & 34 & 40,0 \\
& 40 horas & 32 & 37,7 \\
& 42 horas & 2 & 2,3 \\
& 44 horas & 8 & 9,4 \\
& 72 horas & 2 & 2,3 \\
& 76 horas & 1 & 1,2 \\
Total & Sem resposta & 6 & 7,1 \\
\hline Outro Emprego & & $\mathbf{8 5}$ & $\mathbf{1 0 0}$ \\
& Sim & 25 & 29,4 \\
Total & Não & 60 & 70,6 \\
\hline Setor de Trabalho & & $\mathbf{8 5}$ & $\mathbf{1 0 0}$ \\
Clínica cirúrgica, bloco cirúrgico, central & de & & \\
materiais & & 28 & 32,9 \\
Clinica médica, ortopedia, neurologia & & 19 & 22,4 \\
Pediatria e berçário & & 12 & 14,1 \\
Pronto Socorro Adulto & & 7 & 8,2 \\
Hemodinâmica e cirurgia cardíaca & & 6 & 7,1 \\
Ginecologia e Obstetrícia & & 7 & 8,2 \\
Unidade de Terapia Renal & & 3 & 3,5 \\
Unidade de Infecção Hospitalar & 2 & 2,4 \\
Pronto Socorro Infantil & & 1 & 1,2 \\
\hline Total & & $\mathbf{8 5}$ & $\mathbf{1 0 0}$ \\
\hline
\end{tabular}


A maioria dos entrevistados $(40 \%)$ realizava 36 horas de trabalho por semana, o que resulta na média de 6 horas por dia; os demais $(37,7 \%)$ trabalhavam 40 horas semanais, significando, 6,40 horas diárias; 2,3\% trabalhavam 42 horas semanais; $9,4 \%$ executavam 44 horas de trabalho por semana; $2,3 \%$ referiram trabalhar 72 horas por semana, o que implica a média de 10,2 horas ao dia, 1,2\% referiram trabalhar 76 horas por semana, o que significa 12,4 horas ao dia e $7,1 \%$ não responderam a questão.

A variação de carga horária nesse hospital ocorre, pois os trabalhadores encontram-se regidos por dois vínculos empregatícios, que são: o regime federal e o da FUNEPU (Fundação de Ensino e Pesquisa de Uberaba). Os funcionários da FUNEPU cumprem 36 horas semanais e no presente estudo estão representados por 34 pessoas $(40 \%)$; os contratados pelo regime federal, correspondem a 32 pessoas $(37,7 \%)$ que realizam 40 horas semanais; as outras cargas horárias estão relacionadas aqueles que fazem o horário noturno de 12x36 horas (ou seja, trabalham 12 horas à noite e folgam durante 36 horas) e alguns contabilizaram outros vínculos empregatícios, pois trabalham tanto pelo regime federal quanto contratado por outras instituições.

Em relação ao fato de ter outro emprego, 25 (29,4\%) sujeitos revelaram que o tem e 60 trabalhadores $(70,6 \%)$ que não possuem outro emprego. A necessidade por mais de uma ocupação é evidenciada diante dos insuficientes salários recebidos, uma vez que um auxiliar de enfermagem no HE recebe em torno de $\mathrm{R} \$ 558,00$ (quinhentos e cinqüenta e oito reais) pelo regime federal e $\mathrm{R} \$ 521,00$ (quinhentos e vinte e um reais) pela fundação, o que representa, aproximadamente 
dois salários-mínimos, segundo o mercado de trabalho, correspondendo aproximadamente a US\$176,00 (cento e setenta e seis dólares americanos).

A respeito da carga horária, o estudo de Aquino et al (1993) sobre trabalhadores de enfermagem que atuavam em Salvador, BA, mostrou que a maior duração semanal do trabalho profissional dos auxiliares de enfermagem resultou na média de 45,7 horas e $53 \%$ desses trabalhadores possuíam outra atividade remunerada.

Pitta (1990) descreveu que a necessidade de funcionamento ininterrupto dos hospitais abre as perspectivas de duplo emprego e jornadas prolongadas de trabalho, situação comum, principalmente quando os salários não são suficientes para se manter uma vida com dignidade, dificuldade essa que em geral acontece com os trabalhadores de enfermagem.

Tonhom (1997) constatou em investigação sobre trabalhadores de enfermagem que, de 170, apenas 33(19,41\%) desempenhavam outras funções, incluindo-se as de docente em curso de enfermagem, pedreiro, diarista, trabalhador manual, voluntário, atendente de clínica de vacina, entre outras. Jansen (1997) que realizou estudo sobre acidentes de trabalho entre o pessoal de enfermagem de um hospital de Uberlândia, Minas Gerais, encontrou que $85,4 \%$ dos sujeitos trabalhavam apenas na instituição onde se realizou a pesquisa; portanto, apenas $14,6 \%$ informaram possuir outro emprego.

Alguns autores apontam as inadequações das condições de trabalho em enfermagem, tais como: má remuneração, jornadas exaustivas, não reconhecimento 
e não valorização (Capella \& Gelbecke, 1988; Aquino et al, 1993; Lopes, 1996; Bulhões, 1998; Robazzi \& Marziale, 1999).

A busca por outros vínculos empregatícios pode resolver, em parte, o problema financeiro dos trabalhadores, mas o seu lado pessoal não, principalmente se esses possuem duplo vínculo na área hospitalar, em que a exposição aos riscos e acidentes é maior e, dependendo da carga horária exercida e do local de atuação, duplica-se.

Para os 25 trabalhadores $(29,4 \%)$ que informaram possuir outro emprego, foi-lhes perguntado em que trabalhavam. Vinte e oito por cento desses 25 continuavam realizando suas atividades na enfermagem, 16\% trabalhavam em outros setores da saúde, sendo que $4 \%$ dos auxiliares de enfermagem informaram atuar na área de estética e, o mesmo percentual, realizar atividades com artesanato e educação. A maioria destes 25 sujeitos (52\%), entretanto, deixou a questão sem resposta. Se esses $16 \%$ que informaram trabalhar nas demais áreas da saúde, somarem-se aos 28\% que atuavam na enfermagem, acrescidos daqueles que trabalhavam com os dois distintos empregadores, elevam-se as suas chances de exposição aos diversos riscos ocupacionais, inclusive aos agentes de risco físico, objeto de estudo desta investigação.

No que se refere à quantidade de folgas por semana, 57 dos 60 respondentes $(67 \%)$ que informaram possuir apenas um vínculo empregatício, assinalaram que tinha direito a uma folga, $2,3 \%$ a duas e $1,2 \%$, a mais de duas folgas semanais. 
Quando se contabilizou as folgas em relação aos trabalhadores que informaram ter mais de um vínculo, 16\% responderam que tinha direito a uma folga, $24 \%$, a duas folgas e $4 \%$ a duas ou mais folgas.

É necessário ater-se ao fato que em uma profissão que costuma ser reconhecidamente tão mal remunerada quanto a enfermagem, muitos trabalhadores necessitam realizar outra atividade a fim de ajudar no orçamento familiar. Assim, as folgas devem ser consideradas e respeitadas pelos empregadores, para que as pessoas, não executem o seu trabalho fatigadas e inclusive, coloquem em risco a saúde e a vida dos pacientes que lhes são designados para cuidar, pelo excessivo cansaço que podem vir a apresentar.

Quanto ao fato de realizar trabalho não remunerado, 14 trabalhadores, representando 16,5\%, assinalaram realizar tais atividades, $67(78,8 \%)$ informaram não realizá-las e 4 (4,7\%) não responderam a questão. Dos 16,5\%, que informaram a realização de trabalho não remunerado, $10,5 \%$ referiram trabalhar em casa, $6 \%$ realizavam assistência às comunidades carentes. Sabe-se que as horas dispensadas com as atividades domésticas são árduas e elevam a média de horas trabalhadas por dia. Aquino et al (1993) entendem que essa situação acaba direcionando os trabalhadores ao aparecimento de problemas como fadiga crônica, desgaste físico, além de patologias específicas.

Segundo Aguiar (1988), a forma como a mulher está inserida no mercado de trabalho, a baixa remuneração, o não cumprimento da legislação, que não lhe oferece proteção e condições para cuidar dos filhos, através de equipamentos sociais como as creches, criam condições desfavoráveis que interferem na sua 
situação de saúde. A soma de papéis, a jornada dupla, a desvalorização de seu fazer dentro e fora do lar, contribuem para que ela sofra desgaste físico e mental.

Vianna (1993) comenta que, no Egito antigo, a mulher teve posição de relativa igualdade com a do homem e podia ser comerciante. Já as judias tinham situação de absoluta inferioridade em relação ao homem, não obstante a Lei de Moisés que a colocou no mesmo plano, pois prescrevia que "o matrimônio é a unidade espiritual e corporal do homem e da mulher, como Deus ordenou". A mulher palestina não recebia qualquer instrução e até os treze anos de idade podia ser vendida e casada, segundo a vontade de seus pais. Na Grécia, a mulher só executava trabalhos domésticos, sendo raras e desprezadas aquelas que se dedicavam a qualquer outra atividade; eram educadas com o objetivo de ter filhos belos e sadios. Com o transcorrer dos séculos, não mudou muito essa condição. No Continente Americano, entre os indígenas, especialmente entre os Incas, não passava de escrava, era explorada no seu trabalho, transportando cargas ou fazendo tecidos. No Renascimento, a mulher assume posição de relevo em relação às coisas da inteligência e ciência, com o surgimento de figuras "sábias e enciclopédicas".

Quanto à mulher trabalhadora de hoje, Kauchakje (1999) refere que as sensações de tensão e nervosismo lhes são comuns e tidas como rotina. Esses sentimentos devem-se, principalmente, à desconsideração de seus limites para atender às solicitações internas e externas na sociedade.

A Tabela 2 evidencia ainda que, dos 85 entrevistados, 32,9\% trabalhavam no setor de Clínica Cirúrgica, Bloco Cirúrgico e Central de Materiais. No setor de Neurologia, Clínica Médica e Ortopedia trabalhavam 22,4\%, Na Pediatria e Berçário trabalhavam 14,1\%. No Pronto - Socorro Adulto trabalhavam 
$8,2 \% ; 7,1 \%$ no setor de Hemodinâmica e Cirurgia Cardíaca; $8,2 \%$ na Ginecologia e Obstetrícia; 3,5\% na Unidade de Terapia Renal; 1,2\% no Pronto - Socorro Infantil e 2,4\% na Unidade de Infecção Hospitalar. O Centro de Terapia Intensiva Adulto e Pediátrica não se encontram apresentados na tabela porque os trabalhadores de enfermagem destes setores possuíam nível técnico.

No que se refere aos agentes propiciadores de riscos ocupacionais, mediante o entendimento de que esse tipo de risco pode ser considerado toda situação (fatores, agentes) do ambiente de trabalho que apresenta perigo à integridade física ou mental do trabalhador, foi perguntado aos sujeitos o que entendiam por tal risco. Dos 85 entrevistados, $84,7 \%$ assinalaram a resposta correta, (toda situação - fatores/ agentes - encontrada no ambiente de trabalho, que apresenta perigo à integridade física e/ou mental do trabalhador); $2,4 \%$ deixaram à questão em branco; $10,5 \%$ responderam que é "o conjunto de normas e procedimentos considerados seguros e adequados à manutenção da saúde em atividades que oferecem risco" e 2,4\% assinalaram a alternativa relacionada às "precauções designadas para reduzir o risco de transmissão de microrganismos provenientes de fontes de infecção hospitalar conhecida ou não".

Várias pessoas identificam os riscos "às normas e procedimentos...", o que demonstra o seu desconhecimento sobre o assunto, além dos $2,4 \%$ que os identificaram como sendo "às precauções designadas para reduzir o risco de transmissão de microrganismos..." relacionando-os apenas à questão da infecção hospitalar.

É importante o percentual de auxiliares de enfermagem $(84,7 \%)$ que pareceram entender o que são os riscos ocupacionais. No entanto, esse aparente 
entendimento modifica-se em relação ao que eles manifestaram entender por risco físico, situação essa demostrada na figura a seguir.

Figura 1 - Distribuição de auxiliares de enfermagem de um Hospital Escola, segundo as suas respostas quanto à identificação sobre risco físico. Uberaba, MG, $2003(n=85)$.

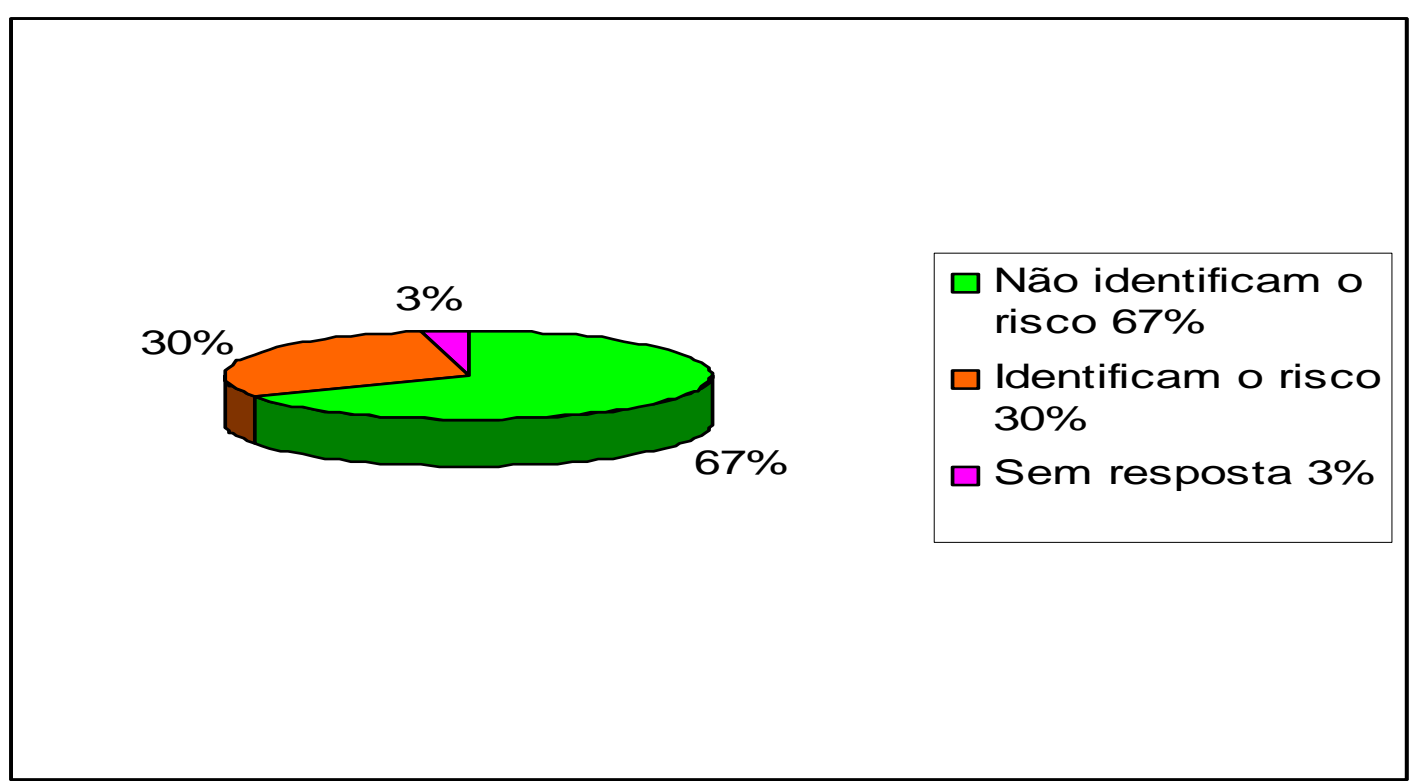

Quanto à identificação do que é o risco físico por parte dos entrevistados, constatou-se que aproximadamente $67 \%$ deles não identificaram o que é esse risco, pois 58,8\% o entenderam como "substâncias que podem entrar no corpo por via respiratória, nas formas de poeira, fumos, névoas, neblinas gases ou vapores, ou que, pela natureza da atividade de exposição, possam ter contato ou ser absorvidos pelo organismo através da pele ou por ingestão" (Miranda, 1998 b), ou seja, confundiram-no com o entendimento do que é risco químico, 8,2\% o identificaram como sendo "microrganismos que invadem o organismo e causam diversas doenças como tuberculose, o tétano, a malária, etc. Apenas 30,6\% (26 dos trabalhadores) o identificaram como sendo "as diversas formas de energia a que possam estar expostos os trabalhadores, tais como: ruído, vibração, pressões 
anormais, temperaturas extremas, radiações ionizantes e não ionizanrtes, bem como o infra-som e o ultra-som" (Miranda, 1998 b). E os demais (2,4\%) deixaram a questão sem resposta. Esses resultados mostram-se contraditórios em relação aos apresentados anteriormente, quando se constatou, nas respostas obtidas, que $84,7 \%$ dos auxiliares de enfermagem responderam que conheciam o que é risco ocupacional, porque haviam assinalado a afirmativa correta.

Acredita-se que o conteúdo sobre riscos ocupacionais deve ser ministrado nas escolas técnicas, porém, de modo superficial, principalmente em relação aos riscos físicos que possivelmente foram abordados de forma muito sucinta, pois os sujeitos desta pesquisa apresentaram dificuldades em responder as questões relacionadas aos mesmos.

Quanto aos fatores/agentes propiciadores de risco físico, as respostas dos entrevistados encontram-se apresentadas na tabela a seguir.

Tabela 3 - Distribuição de auxiliares de enfermagem de um Hospital Escola, segundo as suas respostas quanto à identificação dos agentes propiciadores de risco físico. Uberaba, MG, 2003 (n=85).

\begin{tabular}{lcc}
\hline \multicolumn{1}{c}{ Agentes } & $\mathbf{n}$ & \% \\
\hline Posição do corpo, torção na coluna, carregar peso & 33 & 38,8 \\
Temperaturas extremas, ruído, vibração, umidade & 25 & 29,4 \\
Vírus, bactérias, fungos & 16 & 18,8 \\
Vapores, máquinas, bactérias, ruído & 5 & 5,9 \\
Poeira, iluminação, fungos, gases & 2 & 2,4 \\
Vapores, vibração, parasitas, iluminação & 1 & 1,2 \\
Sem resposta & 3 & 3,5 \\
\hline Total & $\mathbf{8 5}$ & $\mathbf{1 0 0}$ \\
\hline
\end{tabular}

A maioria dos entrevistados $(38,8 \%)$ associou os fatores/agentes de risco físico com a posição do corpo, torção de coluna e carregamento de peso, ou seja, tais 
fatores foram confundidos com a denominação físico, que se atribui ao corpo humano. Percebe-se, então, o desconhecimento existente, tanto em relação ao o que é esse tipo de risco como em relação aos agentes a ele relacionados.

Conforme já foi explicitado anteriormente, os trabalhadores de enfermagem da área hospitalar estão expostos aos vários agentes ocupacionais físicos no seu ambiente de trabalho, tais como a temperatura ambiente elevada em áreas de esterilização, as radiações ionizantes em serviços de radiologia, os ruídos internos e os externos (Marziale, 1995), entre outros.

No entanto, apenas $29,4 \%$ dos entrevistados, no presente estudo, ou seja, 25 pessoas identificaram os fatores de riscos físicos com as temperaturas extremas, ruído, vibração e umidade.

Há vários agentes físicos descritos nas atividades e operações consideradas insalubres, pelo Ministério do Trabalho e Emprego do Brasil, indicadas na Norma Regulamentadora 15 (NR15) (Brasil, 2001). Entre eles, os que podem estar relacionados ao tipo de atividade realizada no ambiente hospitalar são: o ruído, o calor (com diversos níveis de exposição nos ambientes internos e/ou externos); as radiações ionizantes, propiciadas nas atividades de utilização de raios X, bem como na irradiação de espécimes biológicas, no manuseio de amostras irradiadas, as não ionizantes, oriundas de microondas, raios ultravioletas e laser, as vibrações, o frio e a umidade (Mendes, 2003).

Há que se considerar ainda o iluminamento, que deve ter seus valores baseados na unidade de medida lux, que corresponde a um fluxo luminoso de um lúmen por metro quadrado (Oddone et al, 1986). A intensidade de iluminamento necessário para controlar a nocividade devido à iluminação insuficiente é diferente 
conforme as características das ocupações. Nos ambientes do hospital, necessita-se ter o nível de iluminamento correto, pois podem ocorrer problemas de saúde aos trabalhadores submetidos aos níveis inadequados, bem como podem acontecer erros (preparo de medicamentos, por exemplo) que em última instância, vão se refletir nos pacientes a serem atendidos pelos prestadores de cuidados à saúde.

A NR 17 (Brasil, 2001) trata legalmente sobre a questão da iluminação e recomenda, através da NBR 5413 da Associação Braisleira de Normas Técnicas (ABNT) os níveis mínimos de iluminação para os ambientes de trabalho. Prescreve a NR - 17 que em todos os locais de trabalho deve haver iluminação adequada, natural, ou artificial, geral ou suplementar apropriada à natureza da atividade (Brasil, 2001). A esse respeito, a ANVISA (2002) explicita que a boa iluminação do ambiente laboral propicia uma elevada produtividade, uma qualidade melhor do produto final, a redução do mínimo de acidentes, a diminuição do desperdício de materiais, a redução da fadiga ocular e geral, a melhor supervisão do trabalho, o maior aproveitamento do espaço, mais ordem e limpeza das áreas e a elevação da moral dos funcionários.

Comprova-se então o desconhecimento que os auxiliares de enfermagem possuem em relação a esses fatores de risco, mesmo que façam parte do cotidiano de sua atividade hospitalar.

Evidentemente que, se possuem tal desconhecimento, torna-se-lhes difícil reivindicar melhorias nas suas condições laborais, que lhes poderiam ser propiciadas como, por exemplo, sendo-lhes fornecido o uso de equipamentos de proteção individual (EPI) adequados, restringindo-se a nocividade de alguns desses agentes de risco através de equipamentos de proteção coletiva (EPC), além de 
mudanças na própria organização do trabalho, realocando-se os trabalhadores para outros locais com a presença de menor número de fatores de risco, entre outras. E, inclusive, aos que trabalham em um dos empregos nos setores de raios $\mathrm{X}$, no outro vínculo, deveriam trabalhar em locais sem a presença desse tipo de radiação ionizante, entre outras situações.

Para melhor avaliar a questão dos agentes propiciadores de riscos físicos, identificados pelos auxiliares de enfermagem sujeitos do presente estudo, a autora, no período da coleta de dados, observou e identificou nos setores onde realizou as 85 entrevistas, a presença desses agentes como: iluminação inadequada, propiciada por lâmpadas pequenas ou sem lâmpadas, por exemplo; presença de ruídos, (proporcionado pelo excesso de pessoas em horários de visitas de familiares aos pacientes, presença de alunos, sons de campainhas dos quartos e de vários telefones), temperaturas baixas no bloco cirúrgico, onde há a presença de ar condicionado e nos serviços de raios X; temperaturas elevadas na central de material e enfermarias, entre outros, visto que os trabalhadores estão distribuídos em vários setores do hospital, conforme explicado anteriormente e nesses locais há variação dos agentes propiciadores de risco físico em decorrência dos tipos de atividades realizadas.

A Tabela 4 mostra os resultados relativos aos problemas de saúde autoreferidos que acometeram 60 dos auxiliares de enfermagem (70,58\%), visto que os demais $25(29,41 \%)$ declararam não terem apresentado tais problemas. 
Tabela 4 - Distribuição de alterações de saúde relatadas por 60 auxiliares de enfermagem de um Hospital Escola. Uberaba, MG, 2003 (n= 102).

\begin{tabular}{|c|c|c|c|}
\hline CID-10 & DESCRIÇÃO & $\mathbf{n}$ & $\%$ \\
\hline M $54.9 / 54.5$ & Dorsalgia não especificada + Dor lombar baixa & 22 & 21,57 \\
\hline $\mathrm{R}-51$ & Cefaléia & 14 & 13,73 \\
\hline $\begin{array}{l}\text { J } 0.4 / \mathrm{J} 32.9 / \mathrm{J} 03.9 / \\
\text { J } 20.9 / \mathrm{J} 70.9\end{array}$ & $\begin{array}{l}\text { Rinite alérgica não especificada }+ \text { sinusite crônica não } \\
\text { espcificada }+ \text { Amigdalite aguda, não especificada } \\
\text { +Bronquite aguda não especificada }+ \text { Afecções } \\
\text { respiratórias devido a agentes externos não especificados }\end{array}$ & 10 & 9,80 \\
\hline I 15.9 & Hipertensão secundária não especificada & 09 & 8,82 \\
\hline M- 79.1/ M 79.6 & Mialgia + Dor em membro & 06 & 5,90 \\
\hline N 51.9 & Transtorno não especificado de disco intervertebral & 04 & 3,92 \\
\hline Z- 73.3 & Estresse não classificado em outra parte & 04 & 3,92 \\
\hline L 23.9 & $\begin{array}{l}\text { História pessoal de alergias a drogas, medicamentos e } \\
\text { substâncias não especificadas }\end{array}$ & 04 & 3,92 \\
\hline X 50 & $\begin{array}{l}\text { Excesso de exercícios e movimentos vigorosos ou } \\
\text { repetitivos }\end{array}$ & 03 & 2,94 \\
\hline E- 20 & Hipotireoidismo & 03 & 2,94 \\
\hline J 11 & Influenza (gripe) & 03 & 2,94 \\
\hline H- 60.9 & Otite externa não especificada & 02 & 1,96 \\
\hline Н 83.0 & Labirintite & 02 & 1,96 \\
\hline E- 14 & Diabetes mellitus não especificado & 02 & 1,96 \\
\hline I 26/ I 82 & $\begin{array}{l}\text { Embolia pulmonar + Outras embolias e tromboses } \\
\text { venosas }\end{array}$ & 02 & 1,96 \\
\hline M- 43 & Torcicolo & 01 & 0,98 \\
\hline F 89 & $\begin{array}{l}\text { Transtorno do desenvolvimento psicológico não } \\
\text { especificado }\end{array}$ & 01 & 0,98 \\
\hline F 41.9 & Transtorno ansioso não especificado & 01 & 0,98 \\
\hline F 32 & Episódio depressivo & 01 & 0,98 \\
\hline I 83 & Varizes dos membros inferiores & 01 & 0,98 \\
\hline N 39.0 & Infecção do trato urinário de localização não especificada & 01 & 0,98 \\
\hline R 58 & Hemorragia não classificada em outra parte & 01 & 0,98 \\
\hline M 19.9 & Artrose não especificada & 01 & 0,98 \\
\hline M 77 & Esporão do calcâneo & 01 & 0,98 \\
\hline R 52.9 & Dor não classificada em outra parte & 01 & 0,98 \\
\hline H 57 & Outros transtornos do olho e anexos & 01 & 0,98 \\
\hline I 51 & $\begin{array}{l}\text { Complicações de cardiopatias e doenças cardíacas mal } \\
\text { definidas }\end{array}$ & 01 & 0,98 \\
\hline
\end{tabular}

Total $102 \quad 100,00$

*Esta tabela possui $\mathbf{n}=102$, visto que alguns auxiliares de enfermagem referiram apresentar mais de uma alteração de saúde.

Para melhor compreensão das alterações de saúde, referidas pelos 60 auxiliares de enfermagem foi utilizado a CID - 10, com o intuito de identificar e agrupar estas alterações dando-lhes uma linguagem universal através da classificação internacional em questão. 
Excetuando-se 25 trabalhadores $(29,41 \%)$ os quais informaram não ter problemas de saúde ou não responderem esta questão, os demais 60(70,59\%), verbalizaram a presença de uma ou mais alterações, totalizando 102 tipos de problemas de saúde, o que evidencia o fato dos auxiliares de enfermagem estarem trabalhando adoecidos.

Assim, a tabela 4 mostra que $22(21,57 \%)$ das alterações de saúde relatadas referem-se à dorsalgia não especificada e dor lombar baixa, que parecem constituir-se num dos problemas que mais acometem os trabalhadores de enfermagem. As lombalgias representaram a terceira maior causa de absenteísmo entre trabalhadores de enfermagem, o que está em concordância com os estudos mais recentes, realizados no Brasil, por Parada et al, 2002; Moraes et al, 2002, Nordin et al, 2003, entre outros. Em estudo sobre as doenças do trabalho, outras doenças e morbidades de trabalhadores de um hospital de Ribeirão Preto - SP, Franco (1981) detectou as lombalgias como um importante problema de saúde relacionado ao trabalho, entre estas pessoas.

Ksam (2003) explica que a dor lombar é um dos maiores motivos de sofrimento humano e a maior produtora de incapacidade na faixa etária produtiva, ultrapassando o câncer e a síndrome de imunodeficiência adquirida. Constitui-se em um problema econômico, social e médico.

Couto (2003) também aponta que os distúrbios dolorosos da coluna vertebral - genericamente denominados lombalgias e dorsalgias - constituem-se na maior causa de transtornos de saúde e de absenteísmo relacionado ao trabalho. São freqüentes em ocupações que exigem esforços físicos e assim, a sua grande incidência estão ligados à freqüência com que seus mecanismos causadores são 
acionados no cotidiano do trabalho. Nas atividades de enfermagem, torna-se claro a realização de esforço físico relacionado à assistência, mencionado por autores como Bulhões (1998); Suazo (1999) e Nicolete (2001), entre outros.

Constitui-se a cefaléia um dos principais motivos de atendimento médico, sendo responsável por elevado absenteísmo laboral. Quatorze $(13,73 \%)$ dos sujeitos mencionaram ter cefaléia. Como é um sintoma inespecífico, com causas variadas, algumas podem se relacionar ao trabalho. $\mathrm{O}$ estressse referente ao trabalho pode causar cefaléia e alguns fatores ocupacionais podem agravá-la, o que pode ser minimizado se modificações nas condições laborais forem realizadas (Pereira, et al, 2003). Dores de cabeça e dores no corpo (em geral localizadas na região dos músculos mais utilizados no trabalho) podem também ocorrer como sintomas da síndrome de fadiga crônica (Seligmann - Silva, 1995).

Dez trabalhadores $(9,8 \%)$ referiram apresentar rinite alérgica não especificada, sinusite crônica não espcificada, amigdalite aguda, não especificada, bronquite aguda não especificada e afecções respiratórias devido a agentes externos não especificados.

Nove trabalhadores $(8,82 \%)$ relataram apresentar hipertensão secundária não especificada. As principais causas de hipertensão são doenças renais, endócrinas, coarctação da aorta, o uso de drogas, medicamentos, exposição a substâncias tóxicas, estresse e exposição ao ruído (Dantas, 2003). A hipertensão arterial constitui exemplo típico de doença relacionada ao trabalho que tem que ser abordada pelo setor saúde de forma integral e integrada. Seu papel não pode permanecer limitado ao tratamento dos hipertensos e ao pagamento da incapacidade provocada pela hipertensão (Mendes, 1998). Em estudo sobre a enfermagem em um 
hospital geral, Santos (1996) apoiado por Rego (1993) e Araújo (1992) registraram a incidência significativa de sofrimento psíquico e hipertensão arterial neste grupo de trabalhadores.

Seis trabalhadores $(5,9 \%)$ mencionaram apresentar mialgia e dor em membros inferiores, que conforme foi explicitado antes pode indicar também uma síndrome de fadiga crônica. O mau uso da mecânica corporal e a sobrecarga muscular prejudicam os trabalhadores de enfermagem (Olarte et al, 1987).

Quatro trabalhadores (3,92\%) informaram apresentar estresse. Identificado como um fator que afeta o desempenho dos trabalhadores de enfermagem, geralmente este problema acontece em conseqüência da falta de recursos humanos e materiais, da monotonia e da falta de incentivos (Olarte et al., 1987).

O estresse é tido como um fator de risco para várias doenças cardiovasculares, como hipertensão arterial, arritmias cardíacas, doença coronariana, infarto do miocárdio e morte súbita. Várias são as situações estressoras presentes no ambiente de trabalho e entre elas, algumas se destacam como: carga de trabalho, insatisfação, alienação, monotonia e frustração, conflitos interpessoais, competição e falta de influência, insegurança no emprego, oportunidade de promoção, grau de responsabilidade no trabalho, horário laboral irregular, trabalho noturno e em turnos (Andrade Filho \& Santos Júnior, 1995), muitas dessas presentes no ambiente laboral e relacionadas ao trabalho executado pelos auxiliares de enfermagem.

Elias (2002) afirma que a realização excessiva de horas extras por trabalhadores de enfermagem, um clima de trabalho tenso e insatisfatório para as relações interpessoais, o prolongamento de jornada de trabalho, que acaba 
intensificando o seu desgaste físico e psicológico são, certamente, fatores desencadeantes para a instalação do estresse.

Outros $4(3,92 \%)$ referiram história pessoal de alergias a drogas, medicamentos e substâncias biológicas não especificadas. Parada et al (2002), referem que vários pesquisadores têm citado que os trabalhadores de enfermagem são mais afetados por alergias e por lesões dorsais ocupacionais; estes problemas alérgicos podem ocorrer pelo grande uso, por parte dessas pessoas de medicamentos e vários outros produtos químicos do tipo detergentes e sabões, o uso constante de luvas de látex, materiais esses que podem ser alergênicos.

Três $(2,94 \%)$ referiram excesso de exercícios e movimentos vigorosos ou repetitivo e similar percentual citaram a gripe e o hipotireoidismo.

Efeitos negativos acontecem em decorrência da carga de trabalho física, mental e psíquica gerada pela excessiva atividade laboral. Alguns desses efeitos são reversíveis, como a fadiga. Já não se pode dizer o mesmo sobre desgaste excessivo, envelhecimento precoce, doenças profissionais e morte prematura (Bulhões 1998).

Dois trabalhadores $(1,96 \%)$ mencionaram otite e igual percentual, labirintite, diabetes mellitus, embolia pulmonar, outras embolias e tromboses venosas.

Os demais, representando $0,98 \%$ cada, mencionaram apresentar: torcicolo, transtorno do desenvolvimento psicológico não especificado, episódio depressivo, artrose não especificada, entre outros.

No estudo realizado por Elias (2002), os problemas de saúde mais citados pelas suas entrevistadas, trabalhadoras de enfermagem hospitalar, foram hipertensão, enxaqueca, hipo e hipertireoidismo, dores nas pernas, dores nos braços 
e nervosismo, constatando-se que a maioria coincide com alterações de saíude citadas pelos sujeitos do presente estudo.

Franco (1981) estudou a incidência de doenças do trabalho, de outras doenças e da morbidade de várias categorias de profissionais, pertencentes a um hospital geral. Esses profissionais, e entre eles a enfermagem, foram agrupados em 26 grupos ocupacionais, estudados e analisados individualmente. Como resultados constatou a presença constante das lombalgias, de doenças alérgicas, fadiga, doenças infecto-contagiosas, acidente de trabalho, enxaquecas, entre os problemas da saúde relacionados ao trabalho. Apontou também como fatores determinantes dos acidentes e doenças, além dos agentes físicos, químicos, biológicos e psicológicos, a sobrecarga de trabalho, os baixos salários, as condições laborais inadequadas e os mecanismos de controle dos trabalhadores.

Considerando-se que doença significa a "falta ou perturbação da saúde”, (Ferreira, 1993), ou ainda "falta de saúde, enfermidade, moléstia; processo com sintomas característicos, que pode afetar o corpo todo ou uma ou várias de suas partes; mal" (Michaelis, 2000), pode-se considerar que a maioria dos auxiliares de enfermagem do presente estudo 60 indivíduos, 70,5\% encontrava-se enferma.

No entanto, todos os relatos de danos à saúde verbalizados por tais trabalhadores não podem ser entendidos como doenças profissionais, que, conforme Miranda (1998) e Mendes (2003), são entidades mórbidas, produzidas ou desencadeadas pelo exercício do trabalho, peculiares a determinadas atividades.

As doenças profissionais podem ter como causa a ação de agentes físicos; não obstante, são muito imprecisos os limites de ação desses fatores que, 
muitas vezes, associam-se para determinar o aparecimento dessas entidades nosológicas. Essa divisão, todavia, justifica-se do ponto de vista didático e é adotada por quase todos os autores (Binder et al, 2003). Elas originam-se do exercício de determinadas profisssões por uma ação lenta e continuada e que podem ser comprovadas pela relação causa-efeito. São específicas, constituindo-se em entidades mórbidas definidas, cuja causa é diretamente identificável num dos fatores do ambiente de trabalho exemplificando-se, há a silicose, o benzolismo e o saturnismo (Oddone et al, 1986).

Nesse sentido, é necessária a existência de um nexo entre a atividade desenvolvida e o problema de saúde apresentado o que, no caso dos sujeitos do presente estudo não acontece, pois, não são apenas em situações laborais que esses trabalhadores podem ter sido acometidos pelas dores de coluna, cefaléias, varizes, hérnias de disco e hipertensão, entre outras.

Em contrapartida, há o problema de saúde não específico. Conforme explicita Mendes (1995), o agravo à saúde dá a idéia de prejuízo, dano, por outro lado, dano significa estrago, deterioração. Tais agravos à saúde podem ser entendidos como inespecíficos ou, como expõe Mendes (1995), são danos produzidos pelo trabalho, mas o impacto sobre a morbimortalidade dos trabalhadores dá-se de forma não específica. Daí chega-se ao entendimento de outras doenças relacionadas ao trabalho. Oddone et al (1986), por enfermidade inespecífica, entendem o conjunto de doenças físicas e psíquicas não diretamente associáveis a uma causa determinada, mas atribuíveis, ao menos em parte, a um ou mais fatores do ambiente de trabalho. Essas compreendem um grupo heterogêneo que vai do cansaço e insônia persistente, aos distúrbios digestivos, à úlcera 
gastroduodenal, às colites, às neuroses, às artroses, à asma brônquica, à hipertensão e a outras doenças, sempre mais freqüentes nas sociedades industriais, das quais não se conhece a origem.

Os problemas de saúde podem, então, ser relacionados aos agentes de riscos ocupacionais, incluindo-se os físicos.

Em relação ao ruído, por exemplo, sabe-se que pode levar ao estresse, que vai interferir nas atividades psicomotoras, produzindo diminuição do rendimento e aumento dos erros e acidentes de trabalho (Benavides, 2000).

A iluminação precária favorece quedas, desgasta precocemente a capacidade visual e propicia fadiga visual, com sintomas de perturbações visuais freqüentemente acompanhadas de cefaléias (Bulhões 1998).

O calor excessivo favorece o aprecimento de cãibras e espasmos, síncope, edema, fadiga transitória, reações dermatológicas, infertilidade masculina e feminina, má-formação fetal e catarata (Mendes, 2003).

As radiações ionizantes, conforme Benavides (2000), podem propiciar efeitos deterministas que incluem a morte celular, a atrofia de tecidos, as lesões multicelulares (por exemplo, enrijecimento da pele, catarata, náuseas, alterações gástricas, hemorragias e morte).

No que se refere às informações apresentadas na Tabela 4, acredita-se que as alterações de saúde apresentadas pelos auxiliares de enfermagem podem ser devidas aos vários tipos de agentes propiciadores de risco físico, mas podem também ter acontecido, entre outras possibilidades, pelo fato de $29,4 \%$ desses sujeitos possuírem mais de um vínculo empregatício e na própria área da saúde, particularmente em ambiente hospitalar que, como foi descrito, é um local insalubre 
e arriscado e, conseqüentemente, faz os trabalhadores entrarem em contato com agentes propiciadores de riscos biológicos, químicos, ergonômicos, psicossociais, além dos físicos.

Em relação à ocorrência de acidentes de trabalho (AT) que também lhes altera a saúde constatou-se que $44(51,8 \%)$ dos sujeitos relataram ter sofrido e 41 $(48,2 \%)$ referiram não terem se acidentado.

Na década de 70, surgiram alguns textos científicos sobre a questão dos AT. Em 1971, por exemplo, ocorreram 4468 desses eventos em estabelecimentos hospitalares brasileiros. As principais causas foram ferimentos por fragmentos de ampolas e instrumentos cirúrgicos, queimaduras em autoclave e estufas e fraturas por quedas e colisões (Gomes, 1986).

$\mathrm{Na}$ época Subero et al (1987) explicam que os AT vinham crescendo progressivamente, o esforço excessivo ou os movimentos violentos eram as suas principais causas no hospital, a falta de treinamento do pessoal mais jovem também foi tida como uma das causas desses eventos.

Bulhões (1994) cita Rogers \& Haynes em 1991, nos Estados Unidos, que analisando programas de saúde de trabalhadores de 230 hospitais das mais diversas regiões do país, encontram que as enfermeiras foram as mais atingidas por picadas de agulhas, entre outros.

Os estudos foram sendo incrementados e, mais recentemente vários autores são unânimes em apontar o tema como relevante e apresentar elevados percentuais de AT, mesmo havendo subnotificação acidentária, que parecem ocorrer com freqüência, entre os trabalhadores de enfermagem (Pitta, 1992; Takeda, 1996; 
Benatti, 1997; Jansen, 1997; Napoleão, 1999; Silva, 1999; Marziale, 1999; Nicolete, 2001; Barbin, 2003, entre outros).

Entende-se por AT aquele que ocorre pelo exercício do trabalho a serviço da empresa, ou pelo exercício do trabalho dos segurados, referido no inciso VII do artigo da Lei ${ }^{\circ}$ 8213, de 1991, provocando lesão corporal ou perturbação funcional que cause a morte ou perda ou redução permanente ou temporária, da capacidade para o trabalho (Carmo et al, 1995)

Podem ser definidos também como todas as ocorrências não programadas, estranhas ao andamento normal do trabalho, das quais poderão resultar danos físicos e/ou funcionais ou morte do trabalhador e prejuízos materiais e econômicos à empresa (Zocchio, apud Dela Coleta, 1991).

Em geral, para a empresa, um AT representa uma interrupção do processo de produção e esse fato ocasiona um custo imediato; já, para o trabalhador, o acidente mostra-se como um evento traumático, que pode conduzi-lo à morte ou ao afastamento, de forma definitiva, do trabalho (Augusto et al, 1986).

A legislação também equipara ao AT diversas ocorrências com o trabalhador, tais como: agressões, atos de negligência, imperícia e imprudência de terceiros, atos de sabotagem ou terrorismo, ofensas físicas intencionais, entre outras (Oliveira, 1992; Carmo, et al, 1995).

Na vivência desta autora como enfermeira do trabalho e docente, a maior incidência de AT que tem analisado encontra-se relacionada aos riscos biológicos, geralmente, em decorrência de condições inseguras de trabalho, mas, percebendo-se também, em algumas situações, atos de imprudência de alguns colegas. 
$\mathrm{Na}$ presente investigação, alguns AT não foram notificados, pois, segundo o relato dos trabalhadores, comunicá-los demora muito, por se ter que preencher a Comunicação de Acidente de Trabalho (CAT), passar por avaliação médica e realizar exames, entre outros fatores, considerados dificultadores.

Além disso, as subnotificações acidentárias ocorrem devido às dificuldades que o trabalhador tem de identificar o que é um AT. Acresce-se, a esse fato, o agravante de que ele, muitas vezes, apresenta temor em realizar a notificação, porque há a conotação do acidente como um erro, como negligência, o que evidentemente acaba desestimulando-o a realizar a notificação, já que "comete um erro" * deve admitir uma culpa, diante de suas chefias.

Essa situação foi constatada, entre trabalhadores de enfermagem por Napoleão (1999), que evidenciou importante subnotificação acidentária, devido ao medo dos trabalhadores de perderem seus empregos.

Leme et al (1994), em estudo sobre os aspectos epidemiológicos dos AT ocorridos em um hospital de Campinas, SP, apontam que o cansaço e as dificuldades para a notificação acidentária são fatores que podem determinar a subnotificação dos mesmos entre os trabalhadores do turno noturno.

Benatti (1997) comenta, em seu estudo sobre trabalhadores de enfermagem de Campinas - SP, que, em vários casos, eles não sabiam onde notificar o acidente, percorrendo caminhos sempre diversos e muitas vezes preferiam interromper a notificação face às dificuldades encontradas em seu percurso.

Napoleão (1999), em sua investigação, verificou que em relação à categoria funcional, a resposta "lesão pequena, acha que não tem importância" foi

\footnotetext{
${ }^{*}$ As aspas são da autora, MPR, 2003.
} 
apontada principalmente pelos auxiliares de enfermagem, seguido dos atendentes de enfermagem, como justificativa para a não notificação do AT.

Torna-se preocupante uma resposta como essa, pois uma lesão pequena pode estar relacionada aos materiais perfurocortantes, expondo os trabalhadores ao risco de contaminação por $\mathrm{HIV}$, hepatite $\mathrm{B}$ e $\mathrm{C}$, entre outros.

No que se referem aos AT, as entrevistadas de Elias (2002), num primeiro momento, também os banalizaram, principalmente aqueles ocorridos com agulhas, por elas chamados de "comuns". Em geral, omitem tais acidentes que são considerados como parte do trabalho de enfermagem.

Evidencia-se que existem trabalhadores de enfermagem que têm medo de identificar o acidente, outros o categorizam como parte de sua atividade, como se fosse inevitável de acontecer. Quando o trabalhador refere que o acidente compõe as suas atividades, acredita-se que é uma forma que ele acaba encontrando de omitir os erros, as deficiências e as dificuldades presentes na execução do seu trabalho.

As informações em relação à questão "Caso tenha sofrido um AT qual tipo de risco e qual fator" estão demonstradas na tabela a seguir. 
Tabela 5 - Distribuição de auxiliares de enfermagem de um Hospital Escola, segundo as suas respostas sobre os riscos ocupacionais e fatores propiciadores de riscos. Uberaba, MG, $2003(n=47)$

\begin{tabular}{lcc}
\hline \multicolumn{1}{c}{ Risco } & N & \% \\
\hline Biológico & 38 & 80,9 \\
Mecânico & 4 & 8,5 \\
Ergonômico & 4 & 8,5 \\
Físico & 1 & 2,1 \\
\hline Total & $\mathbf{4 7}$ & $\mathbf{1 0 0}$ \\
\hline \multicolumn{1}{c}{ Fator } & $\mathbf{N}$ & $\mathbf{\%}$ \\
\hline Agulha & 25 & 53,2 \\
Lâminas & 12 & 25,6 \\
Esforço físico & 5 & 10,6 \\
Sangue & 2 & 4,3 \\
Ordenha & 1 & 2,1 \\
Compressão dos nervos & 1 & 2,1 \\
Despreparo profissional & 1 & 2,1 \\
\hline Total & $\mathbf{4 7}$ & $\mathbf{1 0 0}$ \\
\hline
\end{tabular}

Em relação especificamente às 47 pessoas que informaram ter sofrido AT, identifica-se, pela tabela anterior, que, dos riscos ocupacionais apresentados, a maioria $(80,9 \%)$ desse total de trabalhadores relacionaram tais AT aos riscos biológicos, sendo que $8,5 \%$ mencionaram que os acidentes poderiam estar relacionados aos riscos ergonômicos e mecânicos e apenas um trabalhador $(2,1 \%)$ associou o AT ao risco físico, o que demonstra, mais uma vez, o desconhecimento dos auxiliares de enfermagem estudados em relação a tais riscos.

Em relação aos fatores propiciadores de riscos, dos 47 participantes do presente estudo, 53,2\% referiram perfuração com agulha, 25,6\%, cortes com lâminas, $10,6 \%$, esforço físico, 4,3\%, exposição ao sangue, $2,1 \%$, ordenha e com o mesmo percentual, o despreparo profissional e a compressão dos nervos. 
Nas suas justificativas não conseguiram adequar o risco ao seu respectivo fator o que demonstra o seu incipiente desconhecimento sobre esse assunto.

Sabe-se, por exemplo, que a agulha, as lâminas são instrumentos, o sangue é um veículo, porém todos foram citados como fatores pelos auxiliares de enfermagem.

Esta pesquisadora surpreendeu-se quando um sujeito (entre os 47) verbalizou acidentar-se por despreparo profissional; observa-se que o trabalhador também reconhece as suas dificuldades e limitações, o que facilita ao serviço de educação continuada a aplicação de treinamentos mediante as queixas do trabalhador. Assim, é imprescindível um treinamento com os trabalhadores que apresentam dificuldades ou falta de habilidades técnicas para executarem suas atividades, pois podem estar se acidentando e, até mesmo, colocando a vida dos pacientes e as suas próprias, em risco.

Para alcançar o último objetivo, identificar dentre os problemas de saúde que acometem os auxiliares de enfermagem aqueles ocasionados por exposição aos riscos físicos, expõe-se o que se segue.

Considera-se riscos à saúde dos trabalhadores todos os fatores ambientais que podem causar lesão, doença ou inaptidão ou afetar o bem-estar de trabalhadores e da comunidade e não meramente a prevenção de doenças nesses indivíduos (Burguess, 1997).

Os riscos hospitalares podem ser classificados em ambientais e ergonômicos. Os primeiros referem-se aos agentes biológicos, físicos, químicos e mecânicos existentes no meio ambiente. 
Em relação especialmente aos riscos físicos, conforme já foi explicado anteriormente, a legislação nacional os reconhece como as diversas formas de energia como as radiações ionizantes e não ionizantes, o ruído, as temperaturas extremas, as vibrações e as pressões anormais (Galafazzi,1998).

\begin{abstract}
“(...) Os efeitos do ruído sobre o humor, ocasionando irritação, exacerbando a ansiedade, são de considerável importância (...) condições ambientais pouco higiênicas, apertadas, abafadas ou dotadas de outras características incômodas, apresentam também efeitos deprimentes, por se constituírem numa agressão à dignidade, algo que muitas vezes pode ser percebido como degradante" (Silva, 1988).
\end{abstract}

A Figura 2 a seguir mostra os problemas de saúde descritos na literatura relacionados aos agentes de risco físico, podendo-se inferir que tais alterações possivelmente relacionam-se a esses fatores, devendo-se, no entanto, considerar que podem estar associados também aos outros agentes de riscos ocupacionais, presentes no ambiente laboral. 
Figura 2 - Agentes de risco físico e algumas alterações de saúde a eles relacionadas

\begin{tabular}{|ll|}
\hline Agentes de Risco Físico & Alterações de saúde \\
\hline Ruído & Rotura de tímpano, estresse, diminuição do rendimento. \\
\hline Iluminação & Favorece a quedas, fadiga visual, cefaléia. \\
\hline Vibração & $\begin{array}{l}\text { Visão turva, perda do equilíbrio, mal estar, fadiga, falta de } \\
\text { concentração, diminuição do rendimento. }\end{array}$ \\
\hline Radiação ionizante & $\begin{array}{l}\text { Hemorragias, catarata, náuseas, alterações gástricas, enrijecimento da } \\
\text { pele, morte. }\end{array}$ \\
\hline Radiação não ionizante & $\begin{array}{l}\text { Câncer de pele, catarata, envelhecimento prematuro da pele, irritação } \\
\text { da conjuntiva ocular, da coluna, lesão da retina.. }\end{array}$ \\
\hline Umidade & Quedas, problemas respiratórios e alérgicos \\
\hline & $\begin{array}{l}\text { Tonturas, náuseas, cãibras, edema, fadiga, síncope, reações } \\
\text { dermatológicas, queimaduras, infertilidade, má formação fetal, } \\
\text { catarata. }\end{array}$ \\
\hline Calor & $\begin{array}{l}\text { Hipotermia, prurido, diminuição da destreza, eritema pérnio, } \\
\text { sinusites, doenças reumáticas, geladura, queimadura pelo frio, }\end{array}$ \\
urticária, irritação de vias aéreas, alterações da performance e da \\
capacidade para o trabalho, diminuição do tato, da sensibilidade e da \\
força manual.
\end{tabular}

Fonte: (Matoba, 1994; Marziale, 1995; Bulhões, 1998; Benavides, 2000; Leme, 2001; ANVISA, 2002; Duca, 2003; Silva Júnior, 2003; Valverde, 2003)

Quanto às alterações de saúde referidas pelos sujeitos desta investigação, em relação aos agentes de risco físico, encontram-se mostradas na figura que se segue.

Figura 3 - Agentes de risco e alterações de saúde codificados conforme a CID 10 (1993) verbalizados pelos auxiliares de enfermagem.

\begin{tabular}{|ll|}
\hline \multicolumn{4}{|l|}{$\begin{array}{l}\text { Alterações de saúde verbalizados pelos auxiliares } \\
\text { Agentes de Risco Físico enfermagem }\end{array}$} \\
\hline & $\begin{array}{l}\text { Hipertensão secundária não especificada, estresse não } \\
\text { classificado em outra parte, transtorno ansioso não } \\
\text { especificado, labirintite }\end{array}$ \\
\hline Ruído & Cefaléia \\
\hline Iluminação & Problemas respiratórios e alérgicos \\
\hline Umidade & Hemorragias não classificada em outra parte \\
\hline Radiação ionizante & $\begin{array}{l}\text { Mialgias, sinusites, afecccões respiratórias devido a } \\
\text { agentes externos não especificados }\end{array}$ \\
\hline Frio & $\begin{array}{l}\text { História pessoal de alergias a drogas, medicamentos e } \\
\text { substâncias não especificadas, exaustão }\end{array}$ \\
\hline Calor excessivo &
\end{tabular}


Conforme já foi explicado anteriormente, entende-se por ruído "um som que pode causar um efeito negativo sobre a saúde e o bem-estar tanto físico como psíquico das pessoas". Se for de grande intensidade pode produzir, de maneira imediata, uma rotura na membrana do tímpano e outras alterações do órgão da audição que causam a perda da capacidade auditiva; pode levar ainda a efeitos mediados pela reação ao estresse, interferir nas atividades psicomotoras, produzindo diminuição do rendimento e aumento dos erros e acidentes de trabalho (Benavides, 2000). No presente estudo, os auxiliares de enfermagem mencionaram apresentar hipertensão, estresse, labirintite e transtorno ansioso não específico, que podem estar relacionados à presença do ruído.

No que se refere à iluminação, a NR 17 explica que, para os serviços de saúde, deve ser considerado o iluminamento mínimo em lux, por tipo de atividade (Brasil, 2001). Quando precária, a iluminação pode favorecer quedas, reduzir a produtividade, agravar a complexidade do trabalho mental e penalizar, sobretudo, o trabalhador mais idoso, provocar desgaste precoce das capacidades visuais e fadiga visual, com perturbações visuais acompanhadas de cefaléias. Uma boa iluminação, em toda a área hospitalar é indispensável à segurança dos pacientes e trabalhadores de enfermagem. Entretanto, na grande maioria dos hospitais compete aos trabalhadores de enfermagem "adaptar" seu corpo às exigências do trabalho, já que as medidas nos espaços hospitalares não consideram o homem que aí vai trabalhar (Bulhões, 1998). Em relação aos achados do presente estudo, a cefaléia foi uma das alterações de saúde que poderia estar associada a este agente de risco físico.

As radiações ionizantes podem produzir efeitos deterministas e probabilísticos para a saúde. Os primeiros incluem a morte celular, a atrofia tecidual 
e as lesões multicelulares, já citadas anteriormente. Os efeitos probabilísticos podem provocar alteração do material genético da célula, o Ácido desoxirribonucléico (ADN) ou de seus mecanismos de expressão. A lesão em uma única célula pode ser suficiente para provocar alterações como, por exemplo, mutação e câncer (Benavides, 2000). Os auxiliares de enfermagem, sujeitos desta pesquisa apresentaram hemorragias que podem estar associadas a este tipo de radiação.

O calor é uma condição de risco de natureza física freqüente em ambientes de trabalho (Santos Júnior, 2003), entretanto, não afeta somente o trabalhador, mas sim todos os demais segmentos da população. Se demasiado pode levar ao choque térmico; há a exaustão pelo calor provocada pela perda excessiva de líquidos, através do suor, associada à uma grande perda de sal. O trabalhador exausto pelo calor, ainda apresenta sudorese e experimenta sensação de fadiga e fraqueza extremas, além de tonturas, náuseas e cefaléia.

A desidratação ocorre quando a ingestão de líquidos é insuficiente para compensar as perdas pela sudorese excessiva. É um dos mecanismos presentes na fisiopatologia da exaustão. Ainda pode provocar, cãibras e espasmos, síncope, edema, fadiga transitória, insolação, queimaduras, reações dermatológicas, infertilidade masculina e feminina, má-formação fetal e catarata (Santos Júnior, 2003). Os auxiliares de enfermagem do presente estudo apresentaram História pessoal de alergias a drogas, medicamentos e substâncias não especificadas e exaustão como possíveis de ocorrerem por tal agente de risco físico.

O frio causa um balanço negativo entre a produção e a perda de calor pelo organismo, levando à alteração do equilíbrio homeotérmico, causando hipotermia, ou do balanço térmico das extremidades, provocando lesões localizadas. 
A exposição a esse agente pode causar hipotermia, eritema pérnio (condição inflamatória da pele dos membros, induzida pelo frio e caracterizada por eritema, prurido e ulceração), geladura ou queimadura pelo frio, urticária, irritação de vias aéreas e alterações da performance e da capacidade para o trabalho, com diminuição da destreza, do tato, da sensibilidade e da força manual (Santos Junior, 2003). As baixas temperaturas também podem provocar alterações consideráveis, tais como: necrose da pele, pneumonias, gangrenas, mialgias, doenças reumáticas e sinusites, entre outras (Galafassi, 1998). Na presente investigação, evidenciou-se que os trabalhadores auxiliares de enfermagem apresentaram mialgias, sinusites, afecções respiratórias, como problemas possíveis de acontecerem em decorrência do frio.

Quando as atividades são exercidas em locais com umidade excessiva, podem ocorrer danos à saúde dos trabalhadores, quedas, problemas respiratórios e alérgicos, entre outros. Devem-se implantar medidas de controle e segurança para evitar tal exposição (Galafassi, 1998), que fazem o trabalhador sentir-se desconfortável, já que a quantidade de líquido que transpira não consegue ser evaporado, diante da elevada umidade no ar presente em ambientes úmidos. No presente estudo, identificou-se problemas respiratórios e alérgicos como possíveis de acontecer em decorrência deste agente de risco físico.

Partindo do princípio que os trabalhadores de enfermagem estão expostos aos vários tipos de riscos, e que uma das medidas de prevenção aos mesmos é a utilização de Equipamentos de Proteção Individual (EPI), perguntou - se - lhes sobre a utilização dos EPI e medidas de prevenção, sendo suas respostas apresentadas nas tabelas que se seguem. 
Tabela 6 - Distribuição de auxiliares de enfermagem de um Hospital Escola segundo as suas respostas quanto ao uso Equipamentos de Proteção Individual. Uberaba, MG, $2003(n=85)$.

\begin{tabular}{|c|c|c|c|}
\hline & Variáveis & $\mathbf{n}$ & $\%$ \\
\hline \multirow[t]{3}{*}{ Máscara } & $\operatorname{sim}$ & 77 & 90,6 \\
\hline & Sem resposta & 8 & 9,4 \\
\hline & Não & 0 & 0 \\
\hline \multicolumn{2}{|l|}{ Total } & 85 & 100 \\
\hline \multirow[t]{3}{*}{ Gorro } & $\operatorname{sim}$ & 29 & 34,1 \\
\hline & Sem resposta & 56 & 65,9 \\
\hline & Não & 0 & 0 \\
\hline \multicolumn{2}{|l|}{ Total } & 85 & 100 \\
\hline \multirow[t]{3}{*}{ Avental de chumbo } & $\operatorname{sim}$ & 66 & 77,6 \\
\hline & Sem resposta & 19 & 22,4 \\
\hline & Não & 0 & 0 \\
\hline \multicolumn{2}{|l|}{ Total } & 85 & 100 \\
\hline \multirow[t]{3}{*}{ Óculos de Segurança } & $\operatorname{sim}$ & 60 & 70,6 \\
\hline & Sem resposta & 25 & 29,4 \\
\hline & Não & 0 & 0 \\
\hline \multicolumn{2}{|l|}{ Total } & 85 & 100 \\
\hline \multirow[t]{2}{*}{ Protetor auricular } & $\operatorname{sim}$ & 1 & 1,18 \\
\hline & Não & 84 & 98,82 \\
\hline \multicolumn{2}{|l|}{ Total } & 85 & 100 \\
\hline \multirow[t]{3}{*}{ Luvas de procedimento } & $\operatorname{sim}$ & 82 & 96,5 \\
\hline & Sem resposta & 3 & 3,5 \\
\hline & Não & 0 & 0 \\
\hline \multicolumn{2}{|l|}{ Total } & 85 & 100 \\
\hline \multirow[t]{3}{*}{ Luvas especiais } & $\operatorname{sim}$ & 35 & 41,2 \\
\hline & Sem resposta & 50 & 58,8 \\
\hline & Não & 0 & 0 \\
\hline \multicolumn{2}{|l|}{ Total } & 85 & 100 \\
\hline \multirow[t]{3}{*}{ Lavagem das mãos } & $\operatorname{sim}$ & 77 & 90,6 \\
\hline & Sem resposta & 8 & 9,4 \\
\hline & Não & 0 & 0 \\
\hline \multicolumn{2}{|l|}{ Total } & 85 & 100 \\
\hline \multirow[t]{3}{*}{ Uso de uniforme } & $\operatorname{sim}$ & 70 & 82,4 \\
\hline & Sem resposta & 15 & 17,6 \\
\hline & Não & 0 & 0 \\
\hline \multicolumn{2}{|l|}{ Total } & 85 & 100 \\
\hline
\end{tabular}


Evidencia-se que os sujeitos participantes do presente estudo fazem uso dos EPI discriminados no instrumento de coleta de dados, com certa freqüência, além de alguns confundirem as medidas de prevenção com os mencionados equipamentos. Assim, dos 85 respondentes, 90,6\% referiram fazer o uso de máscara e 9,4\% não responderam a pergunta; $34,1 \%$ usavam o gorro e $65,9 \%$ não responderam a questão; $77,6 \%$ referiram usar avental de chumbo, sendo que $22,4 \%$ deixaram a questão em branco; 70,6\% informaram usar óculos de proteção e 29,4\% não responderam a questão. Quanto ao protetor auricular 1,2\% referiu usá-lo e 98,8\% referiram o seu desuso. Esse tipo de EPI foi colocado entre os outros no instrumento de coleta de dados, para avaliar se os sujeitos da pesquisa saberiam discernir sobre a necessidade do seu uso nos setores de trabalho, já que se refere a um dos mais importantes agentes de risco físico e deve ser utilizado, em locais onde os limites de tolerância ao ruído, para quem trabalha 6 horas diárias, ultrapassem 87 decibéis e para quem faz 8 horas diárias não pode ultrapassar 85 decibéis. Quanto ao uso de luvas de procedimentos, 96,5\% referiram usá-las e 3,5\% não responderam; 41,2\% informaram fazer o uso de luvas especiais sendo que desses, 7 (21,8\%) especificaram o uso de luvas estéreis e $1(2,85 \%)$ mencionou o uso de luvas de amianto. Em relação à lavagem das mãos, 90,6\% referiram lavá-las e quanto ao uso de uniforme $82,4 \%$ relataram fazer o uso do mesmo como um EPI; esses dois itens são considerados medidas de proteção e não EPI e, mesmo assim, foram assinalados pelos respondentes. Evidencia-se o não entendimento adequado de EPI e de medidas de prevenção pelos auxiliares de enfermagem. 
Considera-se Equipamento de Proteção Individual (EPI) todo dispositivo de uso individual, de fabricação nacional ou estrangeira, destinado a proteger a saúde e a integridade física do trabalhador (Brasil, 2001).

Deve ser fornecido quando o empregador comprovar a inviabilidade técnica da adoção de medidas de proteção coletiva, ou quando essas não forem suficientes, ou encontrar-se em fase de estudo, planejamento ou implantação ou, ainda, em caráter complementar ou emergencial (Miranda, 1998a).

O uso dos EPI, além de indicação técnica, é uma exigência legal, conforme a Norma Regulamentadora 6 (NR-6), da Portaria 3.214, de 8-6-1978, (Brasil, 2001) que determina obrigações tanto para o empregador como para o empregado, como as seguintes: o empregador é obrigado a: adquirir o tipo adequado de EPI à atividade do empregado; fornecer ao empregado somente EPI aprovado pelo Ministério do Trabalho; treinar o trabalhador sobre seu uso adequado e torná-lo obrigatório; substituí-lo, imediatamente, quando danificado ou extraviado; responsabilizar-se pela sua higienização e manutenção periódica; comunicar ao Ministério do Trabalho qualquer irregularidade observada no EPI adquirido. Quanto ao empregado, deve usar apenas para a finalidade a que se destina; responsabilizar-se por sua guarda e conservação e comunicar ao empregador qualquer alteração que o torne impróprio para o uso (Galafassi, 1998).

No serviço de enfermagem, há alguns EPI que são básicos e é de extrema necessidade o seu uso como os óculos de proteção, máscara, avental e luvas; esses EPI têm ação de proteção e minimizam a exposição a alguns agentes de risco ocupacional. 
Pontos importantes devem ser observados quanto ao uso de EPI na área da saúde: considerar que todo paciente é potencialmente portador sintomático ou assintomático de patógenos transmissíveis; aplicar medidas de proteção padrão para todos os pacientes independente do diagnóstico e na manipulação de equipamentos e/ou artigos contaminados ou suspeitos de contaminação; utilizar avental de manga longa, máscara e luvas, sempre ao manipular paciente portador de microrganismo multirresistente (MR); utilizar avental impermeável ao lavar materiais contaminados; desinfetar com álcool a $70 \%$ os óculos de proteção e o avental impermeável, após o término do procedimento (Fernandes et al, 2002).

As informações relacionadas às medidas de prevenção, para evitar exposição ou os acidentes relacionados ao risco físico, estão apresentadas na tabela que se segue. 
Tabela 7- Distribuição de auxiliares de enfermagem de um Hospital Escola segundo as suas respostas quanto às medidas de prevenção relacionadas aos agentes de riscos físicos. Uberaba, MG, $2003(n=85)$

\begin{tabular}{lccc}
\hline Medidas de Prevenção & Variáveis & n & \% \\
\hline Uso de avental de chumbo & sim & 48 & 56,5 \\
& Sem resposta & 37 & 43,5 \\
& Não & 0 & 0 \\
\hline Total & sim & 85 & 100 \\
\hline Uso de luvas & Sem resposta & 75 & 88,2 \\
& Não & 10 & 11,8 \\
\hline Total & & 0 & 0 \\
\hline Uso de protetor auricular & sim & 85 & 100 \\
& Sem resposta & 35 & 41,2 \\
& Não & 50 & 58,8 \\
\hline Total & & 0 & 0 \\
\hline Uso de óculos de proteção & sim & 85 & 100 \\
\hline Total & Sem resposta & 75 & 88,2 \\
\hline Cuidado com perfurocortante & Não & 10 & 11,8 \\
& sim & 0 & 0 \\
\hline Total & Nem resposta & 85 & 100 \\
\hline Controle do ruído & Não & 74 & 87,1 \\
& Sem resposta & 11 & 12,9 \\
\hline & Não & 0 & 0 \\
\hline & & 85 & 100 \\
\hline & & 44 & 51,8 \\
& & 41 & 48,2 \\
& & 0 & 0 \\
\hline & & 85 & 100 \\
\hline
\end{tabular}

Evidencia-se que, em relação a alguns modos de prevenção, os participantes do presente estudo emitiram respostas considerando as medidas prevencionsitas como EPI e muitos ainda não conseguiram diferenciar aquelas relacionadas aos riscos físicos. O uso avental de chumbo, por exemplo, embora esteja relacionado às radiações ionizantes, é um EPI e foi citado por $56,5 \%$ dos sujeitos como sendo uma medida de proteção; 41,2\% mencionaram o protetor 
auricular (também EPI) como medida de proteção relacionada ao ruído. Ainda quanto a esse fator/agente de risco físico, $51,8 \%$ informou a necessidade de existir o seu controle como uma das medidas de proteção ao risco físico, apesar de já terem mencionado a necessidade do uso dos protetores auriculares.

O uso de luvas $(88,2 \%)$ e igual percentual o uso de óculos protetores e o cuidado com o manuseio de material perfurocortantes $(87,1 \%)$ foram entendidos, pelos respondentes, como sendo também medidas protetoras/preventivas de risco físico, apesar de serem relacionadas aos riscos biológicos. 


\section{CONCLUSÕES}

Considera-se ser o presente estudo relevante por ter evidenciado o fato dos auxiliares de enfermagem do Hospital Escola em Uberaba, MG, não conseguirem identificar os riscos ocupacionais vinculados à área hospitalar, particularmente os físicos, situação essa que não deveria acontecer, já que os fatores/agentes deste risco estão presentes no cotidiano do seu trabalho.

Em relação aos dados biográficos, a maioria dos entrevistados pertencia, predominantemente, ao sexo feminino $(82,3 \%)$. A sua faixa etária encontrava-se entre 21 a 57 anos, sendo a idade média de 31 anos. Em relação ao estado civil, $41,2 \%$ eram casados, $(35,3 \%)$ solteiros e os demais encontram-se em outras modalidades como separados, divorciados, viúvos e amasiados. A maior parte dos entrevistados declarou ter concluído o ensino médio (60\%), sendo que $20 \%$ completaram o ensino fundamental, 5,9\% o nível superior completo e 11,8\% estavam cursando o nível superior.

Quanto aos dados profissionais, constatou-se que, no que se refere à carga horária laboral, a maior parte $(40 \%)$ referiu trabalhar 36 horas por semana, sendo os demais distribuídos em cargas horárias variadas (40, 42, 44, 72, 76 horas). Essa diversificação existe como conseqüência dos trabalhadores terem mais de um vínculo empregatício, além de trabalharem no turno noturno, realizando o horário de 12x36 horas. Em relação a possuírem outro emprego, 29,4\% referiram trabalhar em outro emprego, sendo que $28 \%$ realizam atividades na área da enfermagem, $16 \%$ na área da saúde, mas sem referir que tipo de trabalho e 4\% na área de estética e em igual percentual artesanato e educação; quanto à quantidade de folgas, a maioria (67\%) referiu folgar uma vez por semana. No que se refere a realização de trabalho 
não remunerado, 16,5\% informaram desempenhar atividades assim distribuídas: domésticas e assistência a pessoas em comunidades carentes. Quanto ao setor de trabalho, a maior parte dos sujeitos $(32,9 \%)$ informou atuar na clínica cirúrgica, bloco cirúrgico e central de materiais.

No que se refere ao objetivo de investigar se os auxiliares de enfermagem identificaram no ambiente de trabalho hospitalar em que atuam os agentes propiciadores de riscos físicos, evidenciou-se que poucos $(30,6 \%)$ conseguem identificar o que é este risco (diversas formas de energia a que possam estar expostos os trabalhadores), sendo que a maioria $(58,8 \%)$ o identificou como "sendo as substâncias, compostos ou produtos que possam penetrar no organismo pela via respiratória nas formas de poeira, fumos, névoas, neblinas, gases ou vapores, ou que, pela natureza da atividade de exposição, possam ter contato ou ser absorvidos pelo organismo através da pele ou por ingestão", ou seja, confundiramno com o risco químico.

Quando lhes foi perguntado se identificavam quais eram os agentes de risco físico, evidenciou-se que a maioria $(38,8 \%)$ mencionou serem esses fatores relacionados à posição do corpo, torção da coluna e carregamento de peso. Apenas $29,4 \%$ dos auxiliares de enfermagem mencionaram como sendo esses agentes/fatores as temperaturas extremas, o ruído, a vibração e a umidade.

Quanto ao objetivo de investigar os problemas de saúde que acometem os auxiliares de enfermagem, os sujeitos verbalizaram várias alterações, além de acidentes de trabalho. Entre estas alterações encontram-se as dorsalgias e dores lombares baixas, referidas por $21,57 \%$ dos sujeitos; $13,73 \%$ referiram cefaléia, $9,8 \%$ mencionaram rinite alérgica não especificada, sinusite crônica não especificada, 
amigdalite aguda não especificada, além de bronquite aguda e afecções respiratórias; $8,82 \%$ referiram hipertensão secundária não especificada, 5,9\% mencionaram mialgias e dor em membros inferiores; entre outros; $(51,8 \%)$ dos auxiliares de enfermagem mencionaram ter sofrido acidentes de trabalho e $80,9 \%$ identificam tais acidentes aos riscos biológicos.

Para o alcance do terceiro objetivo que foi identificar dentre os problemas de saúde que acometem os auxiliares de enfermagem aqueles ocasionados por exposição aos riscos físicos, considerando o relato dos trabalhadores e a literatura consultada, constatou-se que os auxiliares de enfermagem apresentavam hipertensão, estresse não classificado em outra parte, transtorno ansioso não especificado e labirintite, que podem estar relacionados ao ruído; hemorragia não classificada em outra parte, que por sua vez, pode ser proveniente das radiações ionizantes; história pessoal de alergias a drogas, medicamentos e substâncias não especificadas e reações dermatológicas, excesso de exercícios e movimentos vigorosos ou repetitivos que podem ser advindas do excessivo calor e da umidade; cefaléia, que pode resultar de inadequada iluminação; mialgias, sinusites, afecções respiratórias devido aos agentes externos não especificados, que podem ser decorrentes do frio. No entanto, acredita-se que muitas dessas alterações ocorrem diante da interação dos agentes de risco físico com os demais agentes relacionados aos outros riscos ocupacionais, como os químicos, biológicos, psicossociais, ergonômicos, entre outros.

Neste estudo, conclui-se que, apesar dos fatores/agentes de risco físico estarem presentes no ambiente de trabalho hospitalar onde atuam, os auxiliares de enfermagem não conseguem, em sua maioria, identificá-los; por outro lado, estes 
trabalhadores apresentaram importantes alterações de saúde, bem como acidentes de trabalho e entre esses problemas de saúde, alguns podem estar relacionados aos agentes/fatores de risco físico presentes no hospital.

Esses problemas, além de outros evidenciados nesta pesquisa, relacionados ao desconhecimento dos sujeitos sobre tais riscos (o uso de equipamentos protetores adequados aos riscos físicos mostrou que 98,8\% dos entrevistados não se protegiam contra o ruído, por considerarem não haver necessidade do uso dos protetores auriculares nos setores de trabalho, por exemplo e referiram se proteger contra raios $\mathrm{X}$, usando, em sua maioria, 77,6\% avental de chumbo) podem levá-los a piorar o seu quadro de adoecimento, fazendo crescer as queixas de alterações de saúde em geral e relacionadas aos fatores de risco físico, em particular ou associadas aos demais fatores de risco ocupacional, existentes no ambiente hospitalar.

Os resultados encontrados deverão ser expostos aos auxiliares de enfermagem e às suas chefias, no sentido de que juntos, encontrem sugestões possíveis de serem implementadas, aceitas pela comunidade de trabalhadores e seus chefes, objetivando minimizar os problemas de saúde e permitir a possibilidade de um processo laboral menos insalubre.

Talvez pelo fato dos parâmetros do ambiente físico, em muitas situações, dependerem do quanto os trabalhadores já se acostumaram com eles, tornam-se imperceptíveis (calor, frio, umidade, iluminação, radiações, ruído, vibração). A sua avaliação acaba sendo inoperante aos trabalhadores que se arriscam, no decorrer de sua vida laborativa, realizando suas atividades sem deles tomarem conhecimento. 
Dessa forma há um favorecimento para o seu adoecer e sofrer acidentes de trabalho, pois não conseguem relacionar tais problemas a esses fatores.

Torna-se imprescindível a educação permanente em serviço para que os trabalhadores adquiram, ao menos, o conhecimento mínimo sobre os riscos físicos; há necessidade também de se repensar o processo de trabalho dessas pessoas. A esse respeito, é preciso sensibilizar as gerências, que admitem os trabalhadores com desconhecimento sobre o assunto em questão e possivelmente sobre outros temas de seu interesse, importantes para realização de trabalho de modo mais saudável.

Programas de educação permanente podem então constituir-se em uma das soluções para minimizar os problemas encontrados. Deve ser um processo que propicie novos conhecimentos, capacitando o trabalhador para executar as suas atividades com maior êxito e menos insalubridade. É extremamente importante que a enfermeira realize grupos de estudos, utilizando periódicos e artigos de conteúdos solicitados pelos auxiliares de enfermagem, para que esses possuam melhor aprendizado e tenham bom desempenho no seu trabalho. Um fator importante são as orientações básicas do funcionamento do serviço e dos possíveis fatores propiciadores de risco a que estão expostos, para os recém-admitidos, pois, assim, saberão como desenvolver o seu trabalho e até mesmo como e a quem se dirigir no caso de sofrerem acidentes laborais.

Acredita-se que esses profissionais tenham recebido orientações sobre os riscos ocupacionais, entre eles os físicos, na sua escola técnica, mas que este conteúdo pode ter sido superficializado e a ênfase maior deve ter sido ministrada em relação ao risco biológico, visto que seus agentes, atualmente, são os mais mencionados na área hospitalar e este risco é considerado o mais grave, quanto à 
exposição do trabalhador, em suas atividades diárias. Entende-se então que a inserção do conteúdo sobre saúde do trabalhador nos cursos de nível médio e na graduação em enfermagem será de grande valia.

É de extrema necessidade a realização de investigações, sobre a realidade laboral dos trabalhadores de enfermagem e, em especial, dos auxiliares de enfermagem, por serem o maior contingente da área de enfermagem; há muito que se estudar sobre o que identificam como riscos ocupacionais e os seus efeitos deletérios sobre a saúde. Facilita-se, assim, a análise desses conhecimentos e a necessidade ou não de treinamentos para os mesmos. 


\section{ANEXOS}

\section{Anexo I}

\section{Instrumento para Coleta de Dados}

$\mathrm{N}^{\mathrm{o}}$ da entrevista:

Data:

\section{I -Dados do Sujeito}

Iniciais do (a) informante:

Data de Nascimento:

Estado Civil: ( ) solteiro ( ) casado ( ) separado ( ) divorciado ( ) viúvo

Grau de escolaridade: ( ) $1^{\circ}$ grau ( ) $2^{\circ}$ grau ( ) nível superior completo

( ) nível superior incompleto Nome do Curso:

sexo: ( ) $\mathrm{M} \quad$ ( ) F

Ocupação:

Horas trabalhadas por semana:

( ) 36 horas ( ) 44 horas ( ) outros

1 - Possui outro emprego?

( ) $\operatorname{sim}($ ) não

Caso afirmativo, em que área?

2 - Quantas folgas você tem direito na semana?

( ) 01 ( )02 ( ) mais de duas 


\section{II - Identificação dos Agentes Propiciadores de Riscos}

3 - Mediante os conceitos relacionados a seguir, o que você entende por risco ocupacional?

a) ( ) É o conjunto de normas e procedimentos considerados seguros e adequados à manutenção da saúde em atividades que oferecem risco de adquirir doenças profissionais.

b) ( ) É toda situação encontrada no ambiente de trabalho, que apresenta perigo à integridade física e/ou mental do trabalhador.

c) ( ) São precauções designadas para reduzir o risco de transmissão de microorganismos provenientes de fontes de infecção hospitalar conhecidas ou não.

4- Você já sofreu algum acidente relacionado a algum risco ocupacional?

( ) $\operatorname{sim}$ ( ) não

Caso afirmativo qual tipo de risco e por qual fator?

5 - $\mathrm{O}$ que você entende por risco físico? Marque a alternativa correta.

a) ( ) São substâncias, compostos ou produtos que possam penetrar no organismo pela via respiratória, nas formas de poeiras, fumos, névoas, neblinas, gases ou vapores, ou que, pela natureza da atividade de exposição, possam ter contato ou ser absorvidos pelo organismo através da pele ou por ingestão.

b) ( ) São microorganismos que invadem o organismo e causam diversas doenças, como tuberculose, o tétano, a malária, etc.

c) ( ) São as diversas formas de energia aque possam estar expostos os trabalhadores. 
6- Marque a alternativa que identifica apenas os agentes físicos.

a) ( ) Poeira, iluminação, fungos, gases.

b) ( ) Vapores, máquinas, bactérias, ruído.

c) ( ) Temperaturas extremas, ruído, vibração, umidade.

d) ( ) Vapores, vibração, parasitas, iluminação.

e) ( ) Posição do corpo, torção na coluna, carregar peso.

f) ( ) Vírus, bactérias, fungos.

7- Quais os problemas de saúde que você tem apresentado?

8- Dentre os problemas de saúde que apresentou você considera que pode ser devido aos agentes de risco físico?

( ) $\operatorname{sim}$ ( ) não

9- Quais os Equipamentos de Proteção Individual (EPI's) que você utiliza para se proteger no trabalho?

a) ( ) máscara

b) ( ) gorro

c) ( ) avental de chumbo

d) ( ) avental de tecido

e) ( ) óculos de segurança

f) ( ) protetor auricular

g) ( ) luvas de procedimentos

h) ( ) luvas especiais, e especificar

i) ( ) lavar as mãos

j) ( ) usar uniforme 
10 - Dos itens abaixo relacionados quais você considera como medidas de prevenção, para evitar exposição ou acidentes relacionados aos agentes físicos?
a) ( ) uso de avental de chumbo
b) ( ) uso de luvas
c) ( ) iluminação adequada
d) ( ) uso do protetor auricular
e) ( ) uso de óculos de proteção
f) ( ) cuidado com perfurocortantes
g) ( ) controle do ruído 


\section{Anexo IV}

Faculdade de Medicina do Triângulo Mineiro

Pesquisadora Responsável: Marina Pereira Rezende

TERMO DE CONSENTIMENTO LIVRE E ESCLARECIDO

\section{ESCLARECIMENTO}

Estamos desenvolvendo um estudo sobre riscos ocupacionais, especialmente os físicos, objetivando identificar os agravos à saúde de auxiliares de enfermagem, resultantes da exposição ocupacional aos riscos físicos.

Sua participação é muito importante e para isso pedimos seu consentimento para realizarmos algumas perguntas sobre riscos físicos e agravos à saúde. Gostaríamos de esclarecer que você tem liberdade para desistir, retirando seu consentimento em qualquer fase ou momento da pesquisa, não tendo, com isso, prejuízo no seu trabalho. Garantimos que serão mantidos sigilo e o respeito, ou seja, o seu nome ou qualquer dado que possa identificá-lo não aparecerá no trabalho. 


\section{Anexo V}

\section{CONSENTIMENTO APÓS ESCLARECIMENTO}

$\mathrm{Eu}$, , residente em , por livre e espontânea vontade aceito participar da pesquisa intitulada "Agravos à saúde de auxiliares de enfermagem, resultantes da exposição ocupacional aos riscos físicos, e permito que as informações que prestarei sejam utilizadas para o desenvolvimento da mesma. Declaro que estou ciente dos objetivos e de ter compreendido as informações dadas pela pesquisadora.

Uberaba, de de

ASSINATURA

TESTEMUNHA 


\section{Referências bibliográficas}

ANDRADE FILHO, A de \& SANTOS JUNIOR, E. A dos. Aparelho cardiovascular. IN: Mendes, R. (org.). Patologia do trabalho. São Paulo: Atheneu, 1995. 311-328 p.

ASSOCIAÇÃO BRASILEIRA DE NORMAS TÉCNICAS (ABNT). Níveis de ruído para conforto acústico. NBR10152, Rio de Janeiro, 1- 4 p. dez/ 1987.

AGUIAR, W.M.de. Condições de trabalho feminino e transtornos mentais: um estudo de prevalência. 1988. Dissertação Mestrado - Faculdade de Medicina, Universidade Federal da Bahia, Salvador.

ALEXANDRE, N.M.C. Ergonomia e as atividades ocupacionais da equipe de enfermagem. Rev. Esc. Enferm. USP, São Paulo, v. 32, n. 1, p. 84-90, 1998.

ALMEIDA, M.C.P de. ROCHA, S.M.M. O Trabalho de enfermagem. São Paulo: Cortez, 1997. 296 p.

ALMEIDA, S. I. C. et al. História natural da perda auditiva ocupacional provocada por ruído. Rev. Assoc. Med. Bras, v.46, n.2, p.143-158, 2000. 
ALVARENGA, K.F. et al. Emissões otoacústicas - produto de distorção em indivíduos expostos ao chumbo e ao ruído. Rev. Bras. Otorrinolaringol, v.69, n.5, p.681-686, 2003.

American Conference of Governmental Indutrial Higienists (Acgih) Associação Brasileira de Higienistas Ocupacionais. Limites de exposição para substâncias químicas e agentes físicos e índices biológicos de exposição. Trad. ABHO. Campinas, 1999.

ANTUNES, R. Adeus ao trabalho? ensaio sobre as metamorfoses e a centralidade do mundo do trabalho.6 ed. São Paulo: Cortez, 1999.155 p.

ANVISA, (Ministério da Saúde). Aspecto de Segurança no Ambiente Hospitalar. Brasília, p. 16 a 29. 2002.

AQUINO, E.M.L; ARAÚJO, M.J.S.; MENZES,G.M.S.\& MARINHO,L.F.B. Saúde e trabalho de mulheres profissionais de enfermagem em um hospital público de Salvador, Bahia. Rev.Bras. Enferm.; Brasília, v. 46, n.3-4, p. 245 -57. 1993.

ARAÚJO, M.J.S. Trabalho invisível - corpo marcado: uma equação a ser resolvida. Informativo da Associação Brasileira de Enfermagem, Brasília, v.36, n. 2, p.8, 1994. 
AUGUSTO, L.G.S. et al. Vigilância epidemiológica de doenças ocupacionais. Rev Bras. de saúde ocupacional, São Paulo, v.14, n. 54, p. 32-64, 1996.

AVENDAÑO, C. et al. Riesgos para la salud de las enfermeras Del sector publico de Chile. Rev. Enfermaria. Chile, v. 30, n. 102, p. 15-26, 1995.

AZAMBUJA, E.P.et al. O Trabalho da enfermagem - um espaço de construção da prevenção do risco e acidente de trabalho. Texto e Contexto Enfermagem, Florianópolis, v. 10, n. 1 ,p. 57-93. 2001.

BARBIN, S.R.C. Análise de acidentes de trabalho notificados por trabalhadores de enfermagem da Secretaria Municipal de Saúde de Ribeirão Preto - São Paulo. 2003. p. 192. Dissertação Mestrado - Escola de Enfermagem de Ribeirão Preto da Universidade de São Paulo. Ribeirão Preto.

BARBOSA, A. Hospitais: fontes de saúde ou de riscos? Rev. De Saúde do Distrito Federal, Brasília, v.6, n.1 e 2, p. 33 - 36, 1995.

BARBOZA, D.B; Soler ZASG. Afastamentos do trabalho na enfermagem: ocorrências com trabalhadores de um hospital de ensino. Rev. Latino-Am. Enfermagem, Ribeirão Preto, v.11, n.2, p.177-183, 2003. 
BENATTI, M.C.C. Acidente de trabalho em um hospital universitário: um estudo sobre ocorrência e os fatores de risco entre trabalhadores de enfermagem. 1997. 239 p. Dissertação Doutorado - Escola de Enfermagem, Universidade de São Paulo.

BENAVIDES, F.G., et al. Salud laboral. Conceptos y técnicas para la prevención de riesgos laborales. $2^{\mathrm{a}}$ ed. Barcelona: MASSON, 2000. $501 \mathrm{p}$.

BINDER, M.C.P. et al. Árvore de causas: método de investigação de acidentes do trabalho. São Paulo: Publisher Brasil, 1995. 446 - 451 p.

BINDER, M.C.P.; ALMEIDA,I.M. Acidente do trabalho: acaso ou descaso. In: Mendes, R. (org.). Patologia do trabalho. São Paulo: Atheneu, 2003. 770 - 804 p.

BRAVERMAN, H. Trabalho e capital monopolista: a degradação do trabalho no século xx. Rio de Janeiro: Zahar, 1980.

BRASIL, Conselho Federal de Enfermagem. O exercício da Enfermagem nas Instituições de Saúde do Brasil: 1982/1983. Rio de Janeiro: CONSELHO Federal de Enfermagem, Associação Brasileira de Enfermagem, 1985. 
BRASIL, Ministério da Saúde. Normas para Projetos Físicos de

Estabelecimentos Assistenciais de Saúde. Brasília, p. 43, 1994.

BRASIL, Ministério da Saúde. Resolução 196/97 sobre pesquisa envolvendo seres humanos. Informe epidemiológico do SUS, v.5, n.2, 1996. Suplemento 3.

BRASIL. Conselho Nacional de Saúde. Resolução n. 196: Diretrizes e Normas Regulamentadoras de Pesquisas envolvendo Seres Humanos. Cad. Ética em Pesquisa, v. 1, n. 1, p. 34-42, 1996.

BRASIL. Ministério da Saúde; Organização Pan-Americana da Saúde no Brasil. Doenças relacionadas ao trabalho: manual de procedimentos para os serviços de saúde. Brasília: Ministério da Saúde do Brasil, 2001.

BULHÕES, I. Riscos do trabalho de enfermagem. Rio de Janeiro: Folha Carioca, 1994. $221 \mathrm{p}$.

Hospitais brasileiros apresentam vários riscos aos seus funcionáios. Rev. Proteção, São Paulo, p.24-25,1996.

Riscos do trabalho de enfermagem. Rio de Janeiro: Folha Carioca, 1998. 
BURGUESS, W.A. Identificação de possíveis riscos à saúde do trabalhador nos diversos processos industriais. Belo Horizonte: Ergo Editora, 1997, p.3.

CAMBISES, P.B.S. SANCHEZ, A.S. Radiações ionizantes x radiações - não ionizantes. Rev. CIPA, São Paulo, p. 40 -41, 2000.

CAPELLA, B. B; GELBECKE, F.L. Enfermagem: sua prática e organização. Rev Bras. Enfermagem, Brasília, v.41, n.2, p.132-39, 1998.

CARMO, J.C. Acidentes de trabalho. In: MENDES, R. Patologia do Trabalho. Rio de Janeiro: Atheneu, 1995. p. $431-55$.

CARNICELLI, M.V.F. Exposição ocupacional à vibração transmitida às mãos: uma revisão sobre o distúrbio vascular periférico. Rev Brasileira de Saúde Ocupacional, São Paulo, v.22, n.82, p.35-44, 1994.

CID -10 / Organização Mundial de saúde; Classificação estatística internacional de doenças e problemas relacionados à saúde. $2^{\mathrm{a}}$ ed. São Paulo: Ed. da Universidade de São Paulo, 1994. 1247 p. 
COCCO, M. I.M. Capacidade para o trabalho entre trabalhadores de uma empresa de tecnologia da informação. Campinas: (Tese - Livre Docência) Universidade Estadual de Campinas, 2002.

COMISSÃO NACIONAL DE ENERGIA NUCLEAR - (CNEN). Diretrizes Básicas de Radioproteção. 12/88.

CONSELHO REGIONAL DE ENFERMAGEM. Estatísticas. Disponível em: http://www.portalCOFEN.com.br. Acesso em 23 nov. 2002.

CONSELHO REGIONAL DE ENFERMAGEM - MG. Legislação e Normas.Belo Horizonte: p. 22-26, junho/2001.

CORREAA FILHO, H.R. et al. Perda auditiva induzida por ruído e hipertensão em condutores de ônibus. Rev. Saúde Pública, São Paulo, v.36, n.6, p.693-701, 2002.

COSTA, M.N.A. A; DEUS, I.N. Riscos ocupacionais em UTI: proteção específica. Rev. Bras. Enfermagem, Brasília, v.42, n. 1-4, p. 106 - 109, 1989.

COUTO, H. A. Doenças osteomusculares relacionadas com o trabalho: coluna e membros inferiores. In: Mendes, R. (org.). Patologia do trabalho. São Paulo: Atheneu, 2003. $1296-1324$ p. 
CUNHA, I.A. et al. Avaliação de ruído e vibração em motosserra: resultados parciais Bragantia, v.57, n.1, p.1, 1998.

CUNHA, P; FREIRE, B; DREXLER, G. Occupational exposure in X-ry diagnosis in Brazil. Rad Protec Dosim; 43 (1-4): 55- 58 p. 1992.

DANTAS, R.A.S. AGUILLAR, O.M. O ensino médio e o exercício profissional no contexto da enfermagem brasileira. Rev. Latino-am, enfermagem, Ribeirão Preto, v.7, n.2, p. 25-32, 1999.

DANTAS, J. Patologia cardiovascular relacionada ao trabalho In: Mendes, R. (org.). Patologia do trabalho. São Paulo: Atheneu, 2003. 1296 - 1324 p.

DELA COLETA, J. A. Acidentes de trabalho: fator humano, contribuições da psicologia do trabalho, atividades de prevenção. 2ed. São Paulo: Atlas, 1991.

DUCA, A.C.L. Radiações eletromagnéticas não-ionizantes: Laser. In: Mendes, R. (org.). Patologia do trabalho. São Paulo: Atheneu, 2003. 681 - 702 p.

ELIAS, M.A. O impacto do trabalho sobre a saúde das trabalhadoras da área hospitalar: um estudo sobre o trabalho e sua relação com a saúde das profissionais 
de enfermagem. 2002, 113 p. Dissertação mestrado, Faculdade de Medicina de Ribeirão Preto da Universidade de São Paulo, Ribeirão Preto.

FARIAS, S.N.P de. Et al. Questões legais sobre a saúde do trabalhador de enfermagem. Rev. Enferm. UERJ, Rio de Janeiro, v.8, n.1, p. 28 -32, 2000.

FARINO, G.N. Riesgos ocupacionales dentro del quirófano. Rev. Venez. Anestesiol, v.3, n.1, p. $136-140,1998$.

FERNANDES, M.V, et al. Manual de procedimento técnicos e administrativos de enfermagem. Londrina: Edeuel, 2002. 242p.

FERRAZ, F.C; SEGRE. M. O conceito de saúde. Rev. Saúde Pública, v. 31 n.5 p. $538-542,1997$.

FERREIRA, A.B de H. O minidicionário da língua portuguesa. 2 ed. Rio de Janeiro: editora Nova fronteira, 2001. p.790.

FIGUEIREDO, C.H.O. Riscos ambientais. Rev. Proteção. Rio de Janeiro, n. 20, v. 4 p. $36-37,1992$.

FILHO, A. A. JUNIOR, E. A. S. In: Mendes, R. (org.). Patologia do trabalho. São Paulo: Atheneu, 1995. $313-326$ p. 
FISCHER, F.M. et al . Tópicos de saúde do trabalhador. São Paulo: Hucitec, 1989. p. 158.

FRANCO, A. R. Estudo preliminar das repercussões do processo de trabalho sobre a saúde dos trabalhadores de um hospital geral. Ribeirão Preto, 1981. 217p. Tese Doutorado - Faculdade de Medicina de Ribeirão Preto, Universidade de São Paulo, Ribeirão Preto.

FRIGOTTO, M.D.M. Enfermagem do trabalho e educação em saúde: modelo de educação conscientizadora para "cipas” de empresas públicas. 1999.

GALAFASSI, M.C. Medicina do Trabalho. São Paulo: Atlas, 1998. p.161.

GOMES, J.R. Saúde ocupacional no hospital. Rev. Paul. de hosp, São Paulo, v. 22, n.6, p.274 -6, 1986.

GOMEZ, C.M, et al. A Construção do campo da saúde do trabalhador: percurso e dilemas. Caderno de Saúde Pública. Rio de Janeiro, v. 13. 1997.

GUEDES, E.M.; MAURO, M.Y.C. (RE) visando os fatores de risco e as condições de trabalho da enfermagem hospitalar. Rev. Enferm. UERJ, Rio de Janeiro, v.9, n.2, p. 144-151, 2001. 
GUIDOTTI, T.L. Occupational health for hospital workers. Am Fam Physician. v.35, n.2, p.137-142, 1987.

JANSEN, A.C. Um novo olhar para o acidente de trabalho na enfermagem: a questão do ensino. Ribeirão Preto, 1997. 170p. Dissertação Mestrado - Escola de Enfermagem de Ribeirão Preto, Universidade de São Paulo, Riberião Preto.

JUNIOR, E. A. S. Tensões por trocas térmicas sobrecarga térmica. Frio*. In: Mendes, R. (org.). Patologia do trabalho. São Paulo: Atheneu, 2003. 704 - 718 p.

KAUCHAKJE, L.A.P. Saúde das Mulheres Trabalhadoras, Enfermeiras: o real e o vivido. Ribeirão Preto, 1999. 169p. Tese Doutorado - Escola de Enfermagem de Ribeirão Preto, Universidade de São Paulo, Ribeirão Preto.

KLINGENSTIERNA U, POPE MH. Body Height and Vibration, Spine, v.12, n.6, p.566-568, 1987.

KSAM, J. Lombalgia quebra de paradigmas. Rev. Cipa, São Paulo, ed. 280 p. 2836, 2003.

KUNRATH, J.I. Radioproteção e dosimetria. Os riscos e o cuidado necessário com radiação ionizante. Rev. Proteção. Porto Alegre, n.43, p.56 - 64, 1995. 
LACAZ, F.A .C. Saúde dos Trabalhadores: cenários e desafios. Cad.. de Saúde Pública. Rio de Janeiro, v.13, s.2,1997.

Qualidade de vida no trabalho e saúde/doença. Rev. Ciência e Saúde

Coletiva, Rio de Janeiro, v.5, n.1, p. 151 - 161, 2000.

LAURELL, A.C.; NORIEGA, M. Processo de produção em saúde: trabalho e desgaste operário. São Paulo: Hucitec,1989.

LE GOFF, J. As doenças têm história. 2 ed, Portugal:Terramar, 1997. 361 p.

LEME, A.M.T.; LUCCA, S.R.; FÁVERO, M. Aspectos epidemiológicos dos acidentes de trabalho em um hospital geral. Revista Brasileira de Saúde Ocupacional, São Paulo, v. 22, n. 894, p. 29-39, 1994.

LEME, O. L. S. Estudo audiométrico comparativo entre trabalhadores de área hospitalar expostos e não expostos a ruído. Rev. Bras. Otorrinolaringol, São Paulo, v.67, n.6, p.837-843,2001.

LEOPARDI, M.T. et al. O Processo de trabalho em saúde: organização e subjetividade. Florianópolis: UFSC, 1999. p. 39-41.

LI LB, Kai M, Takano K, Ikeda S, Matsuura M, Kusama T. Occupational exposure in pediatric cardiac catheterization. Health Phys, Cidade, v.69, n.2, p. 261-4, 1995. 
LIMA, M.N. et al. Como enfrentar o stress. São Paulo: Ícone, 1987. 91 p.

LOPES, G.T. et al. O adoecer em enfermagem segundo seus profissionais: estudos preliminares. Rev. Enferm. UERJ. Rio de Janeiro, v.4, n.1, p. 9-18, 1996.

MCABEE RR, GALLUCCI BJ, CHECKOWAY H. Adverse reproductive outcomes and occupational exposures among nurses: an investigation of multiple hazardous exposures. AAOHN J, v. 41, n.3, p.110-119, 1993.

MANDU, E.N.T \& ALMEIDA, M.C.P. Necessidades em saúde: questões importantes para o trabalho da enfermagem. Rev. Bras. Enfermagem. Brasília, v. 52, n.1, p. 54-66, 1999.

MARZIALE, M.H.P. Condições ergonômicas da situação de trabalho do pessoal de enfermagem em uma unidade de internação hospitalar. 1995. 163 p. Dissertação Doutorado - Escola de Enfermagem de Ribeirão Preto, Universidade de São Paulo, Ribeirão Preto.

MARZIALE, M.H.P. A abordagem ergonômica do trabalho de enfermagem. 1999. 149p. Tese Livre-Docência - Escola de Enfermagem de Ribeirão Preto, Universidade de São Paulo, Ribeirão Preto. 
MARZIALE, M.H.P. et al. Riscos de acidentes no trabalho de enfermagem em centro cirúrgico. Rev. Enferm. UERJ. Rio de Janeiro, v.8, n.2, p. 114 - 120, 2000.

MARZIALE, M.H.P.; RODRIGUES,C.M. A produção científica sobre os acidentes de trabalho com material perfurocortante entre trabalhadores de enfermagem. Rev. Latino - am enfermagem, Ribeirão Preto, v. 10, n.4, p.571- 7, 2002.

MATOBA, T. Pathophysicology and clinical picture of Hand-Arm vibration Syndrome in Japoneses workers. Nagoya J Med Sci 1994 (Suppl.) Japan; 57: 19 $26 \mathrm{p}$.

MEIRELLES, B.H. S. A Enfermagem frente aos riscos do ambiente hospitalar. Cogitare Enferm. Curitiba, v.2, n.1, p. 21 -24, 1997.

MENDES, R. O impacto dos efeitos da ocupação sobre a saúde de trabalhadores: I Morbidade. Rev Saúde Pública. São Paulo, v. 2 p. 311- 326, 1988.

MENDES, R. \& Dias, C.E. Da medicina do trabalho à saúde do trabalhador. Rev Saúde Pública. São Paulo, v.25, n.5, p. 341 - 349, 1991.

MENDES, R. Patologia do trabalho. 2 ed. Rio de Janeiro: Atheneu, 1995. 643p.

MENDES, R. Patologia do trabalho. 2 ed. São Paulo: Atheneu, 2003. p.517 - 721. 
MICHAELIS: Minidicionário escolar da língua portuguesa. São Paulo: melhoramentos, 2000. 658 p.

MIRANDA, A.F. Estresse ocupacional inimigo do enfermeiro. 1998. 157p. Dissertação Mestrado - Escola de Enfermagem de Ribeirão Preto, Universidade de São Paulo, Ribeirão Preto.

MIRANDA, C.R. Introdução à saúde no trabalho. São Paulo: Atheneu, 1998. $109 \mathrm{p}$.

MONTEIRO, A.B.C. Biossegurança no preparo, administração e descarte de agentes antineoplásicos injetáveis pela equipe de enfermagem. 2001. p. 67 e 86. Dissertação de Mestrado - Escola de Enfermagem de Ribeirão Preto, Universidade de São Paulo, Ribeirão Preto.

MORAES, M.A.A. et al. Síntomas músculo-esqueléticos e condições de trabalho de costureiras de um hospital universitário. Rev. Paul Enf, v. 21, n. 3, p. 249-254, 2002.

MURATA, K.; et al. Central and peripheral nervous system effects of hand-arm vibrating tool operation. A study of brainstem auditory-evoked potencial and peripheral nerve conduction. Int Arch Occup Environ Health, v. 62, n.3, p.183$187,1990$. 
NAPOLEÃO, A. A. Causas de subnotificação de acidentes de trabalho: visão dos trabalhadores de enfermagem de um hospital do interior paulista. Ribeirão Preto, 1999. 115 p. Dissertação Mestrado - Escola de Enfermagem de Ribeirão Preto. Universidade de São Paulo, Ribeirão Preto.

NETTO, L.F.S.A; RAMOS, F. R. S. Cultura, identidade e trabalho: inter-relações de conceitos. Rev. Bras. Enfermagem, Brasília, v.53, n.2, p. 213-222, 2000.

NICOLETE, M.das.G.de.P. Acidentes de trabalho um estudo do conhecimento e ocorrência acidentária entre trabalhadores de enfermagem de um hospital do Rio Grande do Norte. 2001. 169 p. Dissertação de Doutorado, Escola de Enfermagem de Ribeirão Preto da Universidade de São Paulo, Ribeirão Preto.

NATIONAL INSTITUTE FOR OCCUPATIONAL. Safety and health criteria for a recommedeet standard. Occupational noise expoisure - Revised criteria Cincinnati (OH): NIOSH, 98 -126 p. 1998 a.

NORDI, M. et al. Instrumentos para avaliar a dor lombar: uma proposta para utilização clínica. Rev. Latino-Am. Enfermagem, mar/abr. 2003, vol. 11, n.2, p. $152-155$.

NOSELLA P. Trabalho e educação. In: Trabalho e conhecimento: Dilemas na educação do trabalhador. ( C. Mynayo-Gomez, G. Frigotto, M. Arruda, M. Arroio \& Nosella, orgs), São Paulo: Cortez; 1989; p. 27-42. 
ODONNE, I. et al. Ambiente de trabalho: a luta dos trabalhadores pela saúde. São Paulo: Hucitec, 1986.

OLARTE, N.A. et al. Identificación de factores de riesgo externo ocupacional del personal de enfermaria del hospital general universitário de la samaritana. [S.1:s.n], 1987.

OLIVEIRA, J. Consolidação das leis do trabalho. São Paulo: Saraiva, 1992.

OLIVEIRA, S. A qualidade da qualidade: uma perspectiva em saúde do trabalhador. Cad. Saúde Pública, Rio de Janeiro: v.13, n. 4, 1997.

PARADA, E.O., et al. Lesões ocupacionais afetando a coluna. Rev. Latino Americana de Enfermagem, Ribeirão Preto, v. 10, n.1, p. 64-69, jan. 2002.

PEREIRA, S.R.S. et al. Doenças do sistema nervoso relacionadas com o trabalho. In: Mendes, R. (org.). Patologia do trabalho. São Paulo: Atheneu, 2003. 1185 $1222 \mathrm{p}$.

PITTA, A.M.F. Hospital. Dor e morte como ofício. São Paulo: HUCITEC, 1990.

POLIT, D.F. HUNGLER, B.P. Fundamentos de Pesquisa em Enfermagem. 3 ed. Porto Alegre: Artes médicas, 1995. p. 124-126. 
PORTO, M.F.S; FREITAS, C.M. Análise de riscos tecnológicos ambientais: perspectivas para o campo da saúde do trabalhador. Cad. Se Saúde Pública, Rio de Janeiro, v. 13, s.2, 1997.

POSSO, M.B.S \& Costa, D.S.P. Riscos potenciais que envolvem o trabalho no ambiente hospitalar. Âmbito Hospitalar, São Paulo, p.13 -18, 1998.

PRAÇA, N. de. S; GRANDI, J. L. A enfermeira obstétrica e a prevenção no risco ocupacional de contaminação pelo vírus HIV em centro cirúrgico. Rev. Bras. Enfermagem, Braília, v.42, n. 14, p. 101 - 105, 1989.

REIS, I.N. Doenças ocupacionais: estudo retrospectivo em unidades hospitalares do DF. HFA - Public. Tec. Cient, v.1, n.2, p. 113 - 122, 1986.

RETAMAR, R.A. Hepatitis y sida: normas de prevencion y recomendaciones anti uma exposicion hepatites and AIDS: strategies for prevention and postexture magement.Dermatol. Argent, v.4, n.2, p. 169-178, 1998.

RIO, R.P; PIRES, L. Ergonomia: fundamentos da ergonomia. $2^{\text {a }}$ ed. Belo Horizonte: Health, 1999, 200p. 
ROBAZZI, M.L.C.C.; MARZIALE, M.H.P. Alguns problemas ocupacionais decorrentes do trabalho de enfermagem no Brasil. Rev. Bras. Enfermagem, Brasília, v.52, n. 3 p. 331-338, 1999.

ROBERTS, R.B. et al. Ocupational expousure to HIV in na urban university hospital setting. Braz. J. infect. dis, v. 4, n. 2, p. 50-62, 1999.

ROCHA, R.; PIRES, H.da. S. Minidicionário. São Paulo: Scipione. 2000.

RODRIGUES, B.M.R.D. O cuidar de crianças em creche comunitária: contribuição da sociologia fenomenológica de Alfred Schütz. Londrina: UEL, 1998. $74 \mathrm{p}$.

ROZGAJ, R. et al. Chromosome aberrations in operating room personnel. Am J Ind Med, v, 35, n. 6, p.642-646, 1999.

ROJAS, A. V. A situação de trabalho do pessoal de enfermagem no contexto de um hospital regional argentino: um estudo sob a óptica da ergonomia. Ribeirão Preto, 1999. Dissertação Mestrado - Escola de Enfermagem de Ribeirão Preto, Universidade de São Paulo, Ribeirão Preto.

SANTANA, V. S.; BARBERINO, J.L. Exposição ocupacional ao ruído e hipertensão arterial. Rev. Saúde Pública, São Paulo, v.29, n.6, p.478-487, 1995. 
SANTOS, E.F. dos. et al. Legislação em enfermagem. Atos normativos do exercício e do ensino de enfermagem. São Paulo: Atheneu, 2000. 367 p.

SANTOS, M.L. dos. O trabalho dos anjos de branco: um estudo em hospital geral público. Rev. Saúde em Debate, v. 51, p. 69-74, 1996.

SANTOS, I.; et al. Fatores predisponentes ao acidente de trabalho na área de enfermagem hospitalar. Rev. Enfermagem UERJ, v.1, n.1, p. 90-9, 1993.

SANTOS JUNIOR, E. A. Tensões por trocas térmicas. Sobrecarga térmica. Frio. In: Mendes, R. (org.). Patologia do trabalho. São Paulo: Atheneu, 2003. $703-720$ p.

SECCO, I.A.de O. Acidentes de trabalho com material biológico na equipe de enfermagem de hospital escola público de Londrina - PR. 2002. 225 p. Dissertação de Mestrado, Universidade de Londrina, Londrina.

SHIGUENO, L.Y.O. O exercício do banho de aspersão um estudo sobre as práticas, as condições de trabalho e a saúde das trabalhadoras de enfermagem. São Paulo: 2000. 98p.

SCHNEIDER, L.O.D. Tópicos de saúde ocupacional em hospitais. In: Vieira, S.I. Medicina Básica do trabalho. $2^{\mathrm{a}}$ ed. Curitiba: Gênesis, 1996, v. 5, p. 173 - 174. 
SILVA, V.E.F Estudo sobre acidentes de trabalho ocorridos com trabalhadores de Enfermagem de um hospital de ensino. Ribeirão Preto, 1988. 176p. Dissertação Mestrado - Escola de Enfermagem de Ribeirão Preto, Universidade de São Paulo, Ribeirão Preto.

SILVA, E. M. GOMES, E.L.R. Enfermagem: realidade e perspectiva na assistência e no gerenciamento. Rev. Latino - Am. Enfermagem. Ribeirão Preto, v.1, n. 1, p. 59-64, janeiro 1993.

SILVA, M.da. A Produção científica sobre a relação trabalho e saúde na enfermagem: questões para debate. Rev. Enferm. UERJ, Rio de Janeiro, v.4, n.1, p. 27-38, maio 1996.

SILVA, V.E.F \& MASSAROLLO, M.C.K.B. A qualidade de vida e a saúde do trabalhador de enfermagem. O Mundo da Saúde, São Paulo, v. 22, n. 5, p. 283 286, 1998.

SILVA, D. M. P.P. O adoecer dos trabalhadores de enfermagem: estudo dos problemas de saúde responsáveis pelo absenteísmo - doença em um hospital universitário. 1999. 131p. Dissertação Mestrado - Escola de Enfermagem de Ribeirão Preto, Universidade de São Paulo, Ribeirão Preto.

SILVA, L. F. Vibrações de corpo inteiro e vibrações localizadas. In: Mendes, R. (org.). Patologia do trabalho. São Paulo: Atheneu, 2003. 551 - 598 p. 
SILVEIRA, R.C.P. As crianças e os adolescentes acidentados no trabalho e atendidos em uma Unidade Distrital de Saúde em Ribeirão Preto (SP). Ribeirão Preto, 2003. 128p. Dissertação Mestrado - Escola de Enfermagem de Ribeirão Preto, Universidade de São Paulo, Ribeirão Preto.

SMITH. B.J; PETERS, R.J. Acoustical and noise control. In: Mendes, R. (org.). Patologia do trabalho. São Paulo: Atheneu, 2003. 518 p.

SUAZO, S.V.V. Contribuição ao estudo sobre acidentes de trabalho que acometem as trabalhadoras de enfermagem em hospitais chilenos. 1999. $200 \mathrm{p}$. Tese Doutorado - Escola de Enfermagem de Ribeirão Preto, Universidade de São Paulo, Ribeirão Preto.

SUAZO, S.V.V.; ROBAZZI, M.L.C.C. Accidentes Del trabajo: la situacion de la mujer Del equipo de enfermeria en dos hospitales clinicos chilenos. Rev. Ciencia y enfermeria. Ribeirão Preto, v. VI, n. 1, p. 67-78, 2000.

SUBERO, R.C.; FERNANDEZ, F.C.; CASTIEL, J.F. A acidentalidade laboral em um hospital geral. Saúde Trabalho, v. 1, n.3, p. 176 - 81, 1987.

TAKEDA, E. Tuberculose: um estudo de sua situação entre pacientes internados e equipe de enfermagem de um hospital escola de Ribeirão Preto. 1996. 157 p. 
Dissertação de Mestrado - Escola de Enfermagem de Ribeirão Preto, Universidade de São Paulo, Ribeirão Preto.

Riscos ocupacionais, acidentes do trabalho e morbidade entre motoristas de uma central de ambulância do Estado de São Paulo. 2002. Tese Doutorado - Escola de Enfermagem de Ribeirão Preto - Universidade de São Paulo, Ribeirão Preto.

TAN, C.C. Occupational health problems among nurses. Scand J Work Environ Health, v. 17, n. 4, p.221-30, 1991.

TEIXEIRA, C. et al Saúde auditiva de trabalhadores expostos a ruído e inseticidas. Rev. Saúde Pública, v.37, n.4, p.417-423, 2003.

TONHOM, S.F.R. Queixas de mal estar entre os trabalhadores da equipe de enfermagem de um hospital geral público. Ribeirão Preto, 1997. 74 p. Dissertação de Mestrado.

UBERABA， 2002. Disponível: http://www.uberaba.mg.gov.br/localizacao.htm Acesso em 20/12/2002.

VALVERDE, N. J.L. Radiações ionizantes. In: Mendes, R. (org.). Patologia do trabalho. São Paulo: Atheneu, 2003. 595 - 637 p. 
VIANNA, S. Trabalho da mulher. In: SUSSEKIND, A. et al. Instituições de direito do trabalho. 14 ed. São Paulo, LTR, 1993. v.2, p. 855-79

VIEIRA, S.I. Medicina básica do trabalho. 2 ed. Curitiba: Gênesis, 1996, v. 4, p. $81-168$. 